\title{
Composition of Natural Gas and Crude Oil Produced From 14 Wells in the Lower Silurian "Clinton" Sandstone and Medina Group Sandstones, Northeastern Ohio and Northwestern Pennsylvania
}

By Robert C. Burruss and Robert T. Ryder

Chapter G.6 of

Coal and Petroleum Resources in the Appalachian Basin:

Distribution, Geologic Framework, and Geochemical Character

Edited by Leslie F. Ruppert and Robert T. Ryder

Supersedes USGS Open-File Report 03-409

Professional Paper 1708 
Suggested citation:

Burruss, R.C., and Ryder, R.T., 2014, Composition of natural gas and crude oil produced from 14 wells in the Lower Silurian "Clinton" Sandstone and Medina Group Sandstones, northeastern Ohio and northwestern Pennsylvania, chap. G.6 of Ruppert, L.F., and Ryder, R.T., eds., Coal and petroleum resources in the Appalachian basin; Distribution, geologic framework, and geochemical character: U.S. Geological Survey Professional Paper 1708, 38 p.,

http://dx.doi.org/10.3133/pp1708G.6. (Chapter G.6 supersedes USGS Open-File Report 03-409.) 


\section{Contents}

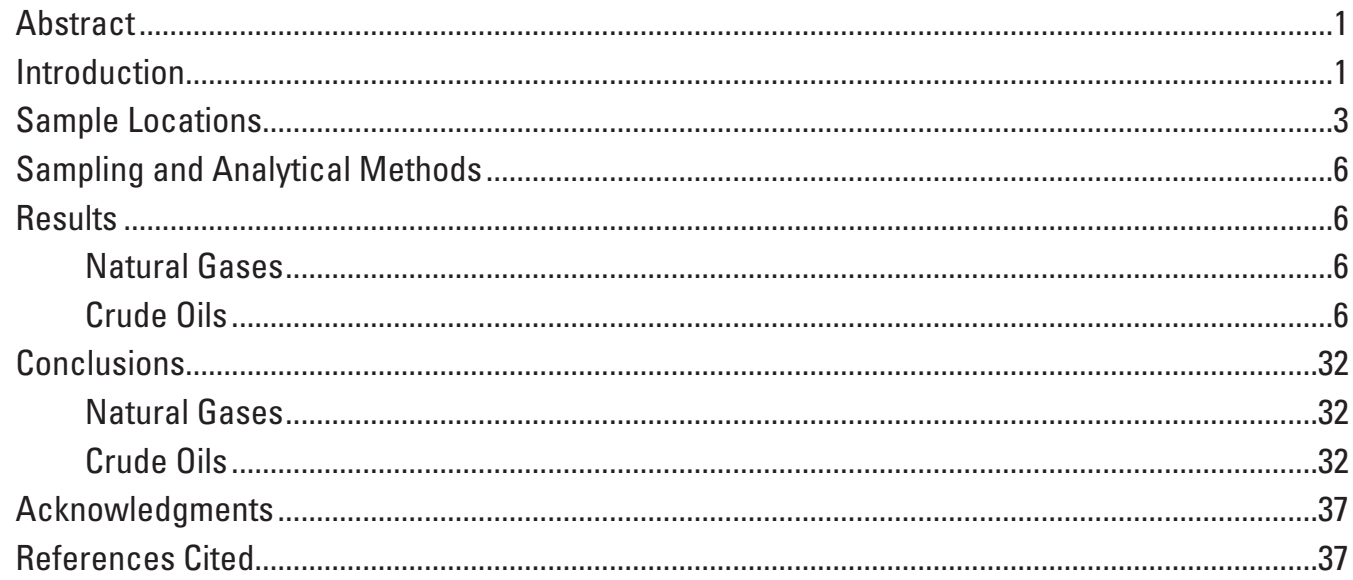

\section{Figures}

1. Map showing the distribution of the Lower Silurian regional oil and gas accumulation in the Appalachian basin, the location of the study area, and cross sections

2. Chart showing stratigraphic nomenclature for Upper Ordovician through Upper Silurian strata, northeastern Ohio and northwestern Pennsylvania

3. Map of the study area in northeastern Ohio and northwestern Pennsylvania showing well locations in Geauga and Trumbull Counties, Ohio, and Mercer and Butler Counties, Pa., where oil and (or) gas was sampled.

4. Schoell diagram showing the isotopic composition of selected natural gases in the Lower Silurian regional oil and gas accumulation.

5-15. Whole-oil, saturated hydrocarbon fraction, and aromatic hydrocarbon fraction gas chromatograms-

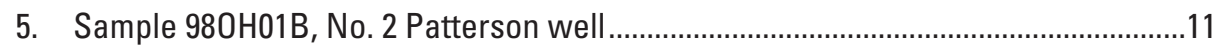

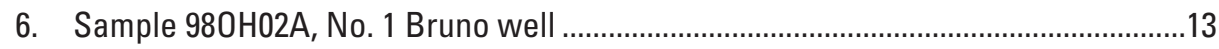

7. Sample 980H03A, No. 2 Grandview-Johnson well...............................................15

8. Sample 980H04A, No. 1 Detweiler well ..............................................................17

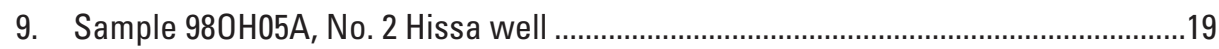

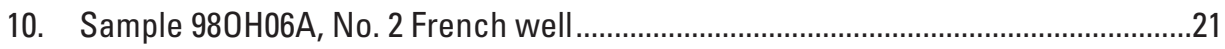

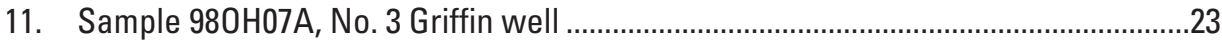

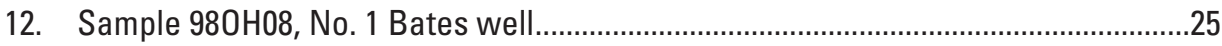

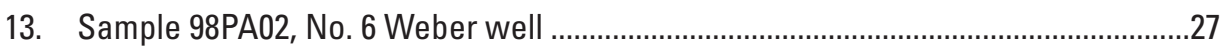

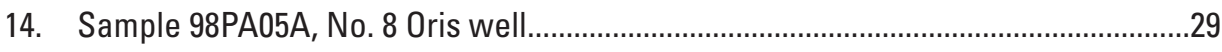

15. Sample 98PA06A, No. 2 Gibson well ..................................................................

16. Plot of $\mathrm{ph} / n-\mathrm{C}_{18}$ versus $\mathrm{pr} / n-\mathrm{C}_{17}$ for "Clinton" sandstone and Medina Group oil samples and Utica Shale bitumen extracts 
17. Plot of $\delta^{13} \mathrm{C}$ distributions in the saturated and aromatic hydrocarbon fraction for "Clinton" sandstone and Medina Group oil samples and Utica Shale bitumen extracts

18. Mass fragmentograms for sample 98PA02 from the No. 6 Weber well.

\section{Tables}

1. Wells sampled for gas and oil in northeastern Ohio and northwestern Pennsylvania.....5

2. Molecular and isotopic composition of gas samples.......................................................

3. Properties of the whole crude oil and crude oil fractions ................................................

4. Properties of the saturated hydrocarbon fraction of the crude oils ..................................

5. Terpane and sterane compounds identified in the saturated fraction of the oil from the No. 6 Weber well, Mercer County, Pa.

\section{Conversion Factors}

\begin{tabular}{lll}
\hline \multicolumn{1}{c}{ Multiply } & \multicolumn{1}{c}{ By } & \multicolumn{1}{c}{ To obtain } \\
\hline & Length & \\
\hline foot $(\mathrm{ft})$ & 0.3048 & meter $(\mathrm{m})$ \\
mile $(\mathrm{mi})$ & 1.609 & kilometer $(\mathrm{km})$ \\
& & \\
micrometer $(\mu \mathrm{m})$ & 0.000039 & inch (in.) \\
millimeter $(\mathrm{mm})$ & 0.03937 & inch (in.) \\
meter $(\mathrm{m})$ & 3.281 & foot $(\mathrm{ft})$ \\
\hline & Volume & \\
\hline cubic foot $\left(\mathrm{ft}^{3}\right)$ & 0.02832 & cubic meter $\left(\mathrm{m}^{3}\right)$ \\
\hline & Velocity & \\
\hline centimeters per second $(\mathrm{cm} / \mathrm{sec})$ & 0.3937 & inches per second (in. $/ \mathrm{sec})$ \\
\hline
\end{tabular}

Temperature in degrees Celsius $\left({ }^{\circ} \mathrm{C}\right)$ may be converted to degrees Fahrenheit $\left({ }^{\circ} \mathrm{F}\right)$ as follows:

${ }^{\circ} \mathrm{F}=\left(1.8 \mathrm{x}^{\circ} \mathrm{C}\right)+32$

Gas is measured in cubic feet using the following terms and abbreviations, which are commonly used in the oil-and-gas industry: standard cubic feet (SCF), million cubic feet (MMCF); and trillion cubic feet (TCF).

The isotopic composition of carbon (carbon $13,{ }^{13} \mathrm{C}$ ) in methane is reported as the deviation (expressed as $\delta^{13} \mathrm{C}$ ) in units of parts per thousand (per mil) relative to the Vienna Peedee belemnite (VPDB) standard.

The isotopic composition of hydrogen (deuterium, ${ }^{2} \mathrm{H}$ ) in methane is reported as the deviation (expressed as $\delta^{2} \mathrm{H}$ ) in per mil relative to the Vienna standard mean ocean water (VSMOW). 


\title{
Composition of Natural Gas and Crude Oil Produced From 14 Wells in the Lower Silurian "Clinton" Sandstone and Medina Group Sandstones, Northeastern Ohio and Northwestern Pennsylvania
}

\author{
By Robert C. Burruss ${ }^{1}$ and Robert T. Ryder ${ }^{1}$
}

\section{Abstract}

The geochemical processes that control the distribution of hydrocarbons in the regional accumulation of natural gas and crude oil in reservoirs of Early Silurian age in the central Appalachian basin are not well understood. Gas and oil samples from 14 wells along a down-dip transect through the accumulation in northeastern Ohio and northwestern Pennsylvania were analyzed for molecular and stable isotopic compositions to look for evidence of hydrocarbon source, thermal maturation, migration, and alteration parameters. The correlation of carbon and hydrogen stable isotopic composition of methane with thermal maturation indicates that the deepest gases are more thermally mature than independent estimates of thermal maturity of the reservoir horizon based on the conodont alteration index. This correlation indicates that the natural gas charge in the deepest parts of the regional accumulation sampled in this study originated in deeper parts of the Appalachian basin and migrated into place. Other processes, including mixing and late-stage alteration of hydrocarbons, may also impact the observed compositions of natural gases and crude oils.

\section{Introduction}

The Lower Silurian regional natural gas and oil accumulation was named by Ryder and Zagorski (2003) for a 400mile (mi)-long by 200 -mi-wide hydrocarbon accumulation in the central Appalachian basin of the eastern United States

\footnotetext{
${ }^{1}$ U.S. Geological Survey, Reston, Va.
}

${ }^{2}$ The "Clinton" sandstone in Ohio was miscorrelated by drillers with strata in the type Clinton Group of New York when in fact it is equivalent to the underlying type Medina Group of New York. Although this miscorrelation has caused confusion in nomenclature, the term continues to be used widely in the literature and by the oil and gas industry. Early drillers correctly identified the informal Medina sandstone in Ohio as a partial equivalent of the type Medina Group of New York. and Ontario, Canada (fig. 1). The dominant reservoirs in this regional accumulation are the "Clinton" sandstone (usage of Ryder, $2000^{2}$ ), the Grimsby and Whirlpool Sandstones of the Medina Group, and the Tuscarora Sandstone of Early Silurian age (fig. 2). The basin-center gas (continuous) part of this regional Silurian accumulation contains an estimated 30 trillion cubic feet (TCF, standard abbreviation used in the oiland-gas industry) of recoverable gas and covers an area that extends across western Pennsylvania, eastern Ohio, and western West Virginia (Gautier and others, 1995; Ryder, 1998). This part of the accumulation occurs in rocks of low permeability, usually 0.1 millidarcies $(\mathrm{mD})$ or less, downdip of more permeable, water-saturated rocks. A conventional part of the accumulation with hybrid features of a basin-center accumulation lies updip from the basin-center gas accumulation (Ryder, 1998; Ryder and Zagorski, 2003). This hybrid-conventional part of the regional accumulation follows a pre-1980s production trend that extends from Ontario, Canada, through western New York, northwestern Pennsylvania, and central Ohio (fig. 1).

In the basin-center part of the regional accumulation, individual wells ultimately produce between 50 and 450 million cubic feet (MMCF, an abbreviation used in the oiland-gas industry) of natural gas. In addition to gas, many wells produce variable amounts of brine and crude oil. The gas-to-fluid ratio is variable but generally high, on the order of 50,000 to 500,000 standard cubic feet (SCF, an abbreviation used in the oil-and-gas industry) of gas per barrel of oil or brine. The amount of oil and brine produced affects the economics of individual wells because of the cost incurred to dispose of the brine or the value added through the sale of oil. In general, the best gas producers are those wells that produce the least oil and brine.

We investigated the geochemistry of the gas and co-produced oil to better understand the origin of the hydrocarbons within the Lower Silurian regional accumulation. This report documents 12 gas samples and 11 oil samples from 14 wells producing from the "Clinton" sandstone and the Grimsby and Whirlpool Sandstones of the Medina Group in northeastern 


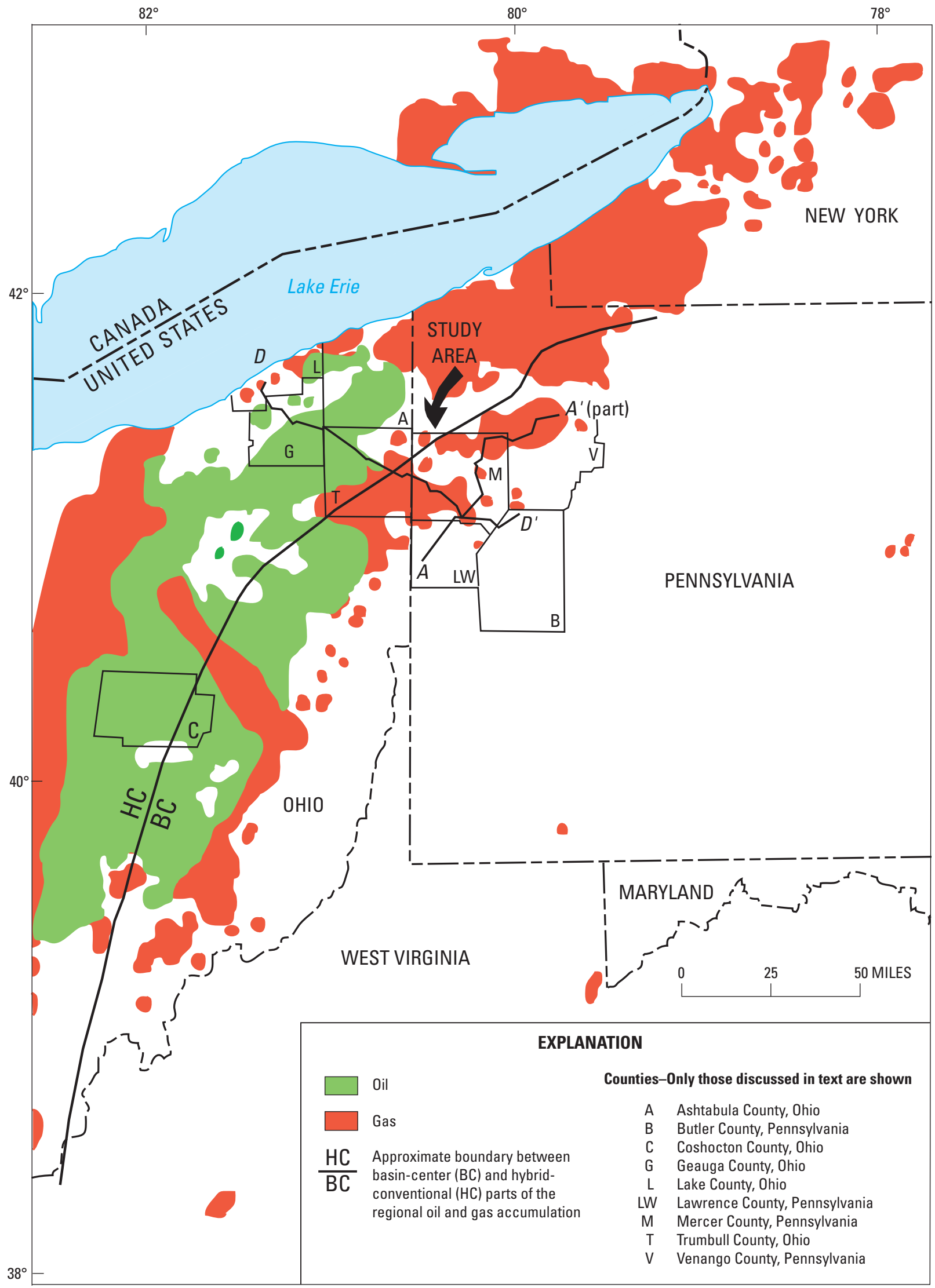

Figure 1. Map showing the distribution of the Lower Silurian regional oil and gas accumulation in the Appalachian basin, the location of the study area, and cross sections $A-A^{\prime}$ of Ryder (2000) and $D-D^{\prime}$ of Keighin (1998). 
Ohio and northwestern Pennsylvania. The samples from Ohio were collected in Geauga and Trumbull Counties and those from Pennsylvania were collected in Butler and Mercer Counties. This investigation supplements a previous data set of 10 oil samples and 3 gas samples collected from the "Clinton" sandstone in Trumbull County (Barton and others, 1998; Burruss and Ryder, 1998).

Other published analyses of crude oils and natural gases from Silurian reservoirs in the Appalachian basin include those by Barker and Pollock (1984), Powell and others (1984), Cole and others (1987), Jenden and others (1993), Drozd and Cole (1994), Laughrey and Baldassare (1998), and Obermajer and others (1998). Cole and others (1987) recognized two groups of oils in Silurian reservoirs in Ohio: (1) oil generated from marine black shale of Devonian age and (2) oil generated from marine black shale of Ordovician age. Most likely, oil in the Lower Silurian "Clinton" sandstone was generated from the Ordovician black shale (Drozd and Cole, 1994; Ryder and others, 1998). Devonian black shale is a less likely source for the "Clinton" oils because the 700- to 1,000-feet (ft)-thick Upper Silurian Salina Group (which contains evaporite beds) is located between them (fig. 2). Molecular and isotopic data on natural gas from Silurian reservoirs in western and central Pennsylvania (Laughrey and Baldassare, 1998) and western New York (Jenden and others, 1993) are less diagnostic for identifying source rocks than geochemical parameters measured in oil samples. However, the general conclusion of work to date on gases from reservoirs in the "Clinton" sandstone and the Grimsby, Whirlpool, and Tuscarora Sandstones is that they were derived from thermally mature, marine, organic matter and that they probably were generated in strata older than the Silurian.

\section{Sample Locations}

The wells sampled for this investigation follow a northwest-southeast trend that is subparallel to the dip of the basin and crosses the approximate boundary between basin-center and hybrid-conventional parts of the Lower Silurian regional accumulation (figs. 1, 3). In general, those wells east of Mosquito Creek Lake in central Trumbull County, Ohio, are located in the basin-center part of the Lower Silurian regional accumulation, whereas those wells west of Mosquito Creek Lake are located in the hybrid-conventional part (fig. 3). All wells sampled are within $5 \mathrm{mi}$ of cross section $D-D^{\prime}$ of Keighin (1998), which shows the stratigraphic and depositional character of the "Clinton" sandstone and Medina Group (fig. 3). Cross section $A-A^{\prime}$ of Ryder (2000), which connects with cross section $D-D^{\prime}$ in Mercer County, is located 5 to 10 mi from the wells sampled in southeastern Mercer and northwestern Butler Counties (fig. 3). Also located in figure 3 are 10 wells in Trumbull County for which oil and gas analyses have been reported by Burruss and Ryder (this volume, chap. G.7). Selected information on the wells sampled for this investigation is listed in table 1.

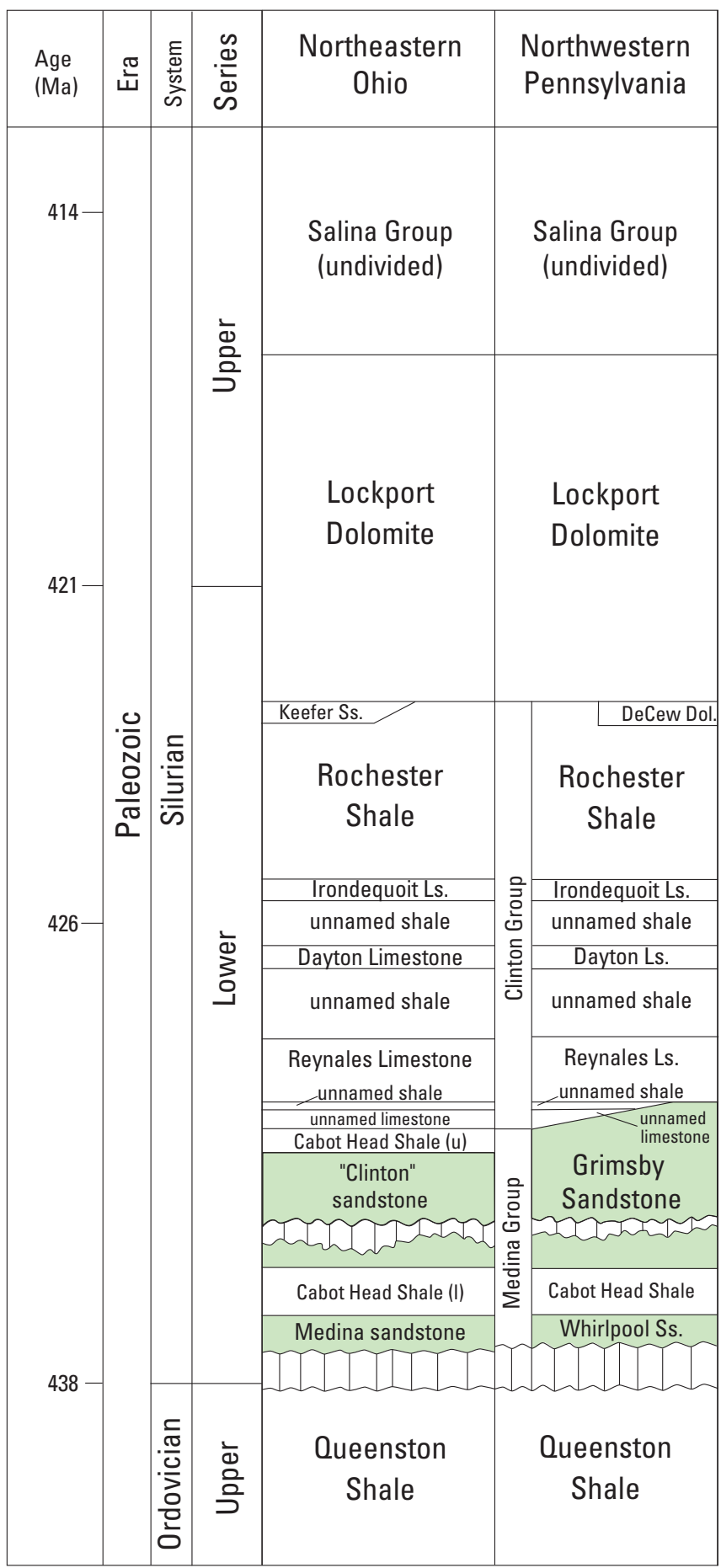

Figure 2. Chart showing stratigraphic nomenclature for Upper Ordovician through Upper Silurian strata, northeastern Ohio and northwestern Pennsylvania. Colored units show the interval of the Lower Silurian regional oil and gas accumulation. Stratigraphy and nomenclature based on Brett and others (1995) and Ryder (2000); time scale of Palmer (1983). Abbreviations are as follows: Dol., Dolomite; Ls., Limestone; I, lower part; Ss., Sandstone; u, upper part. 


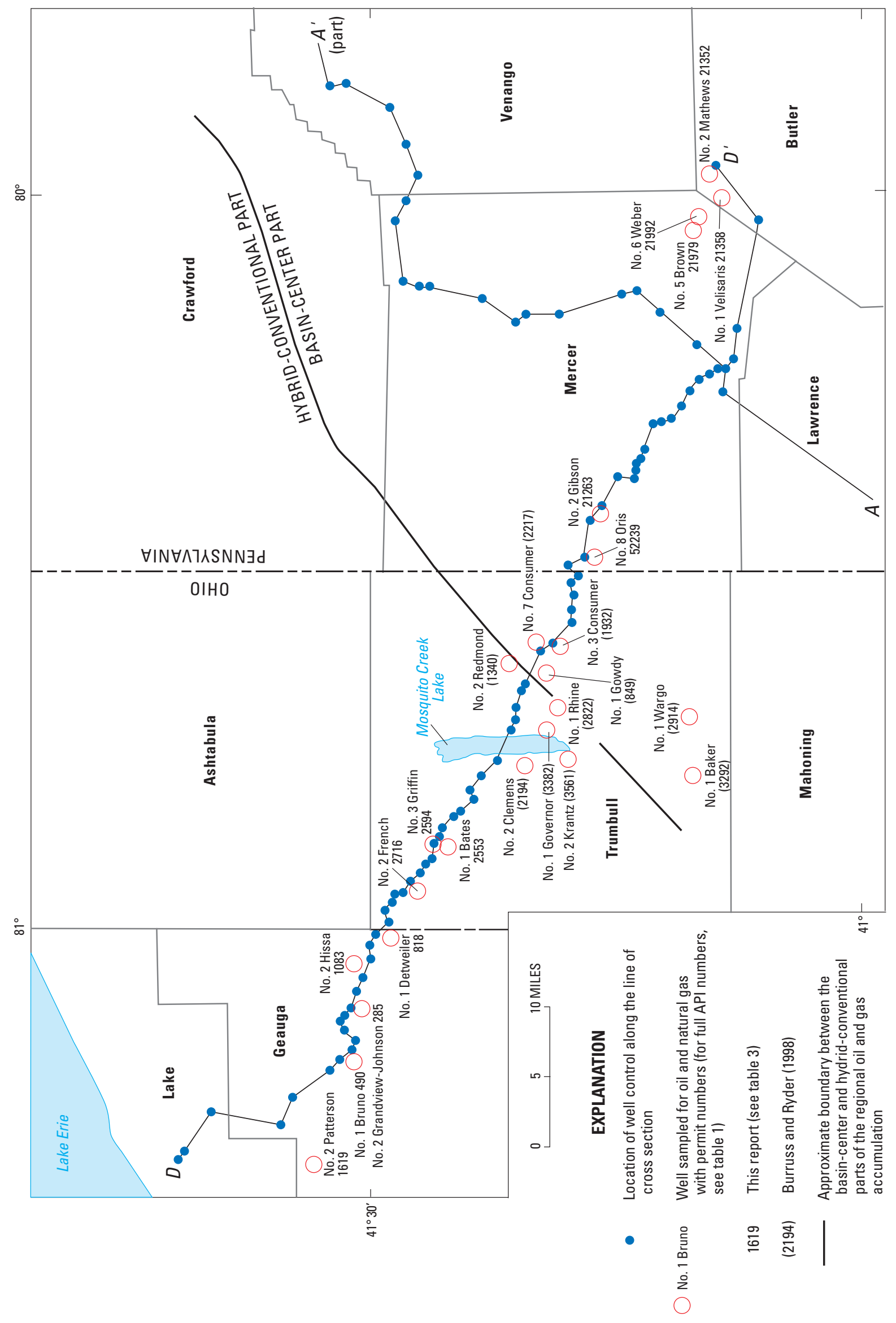

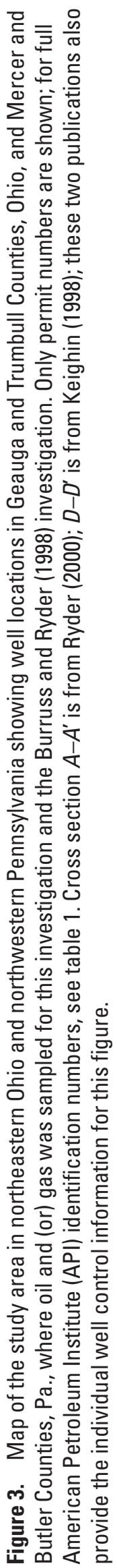




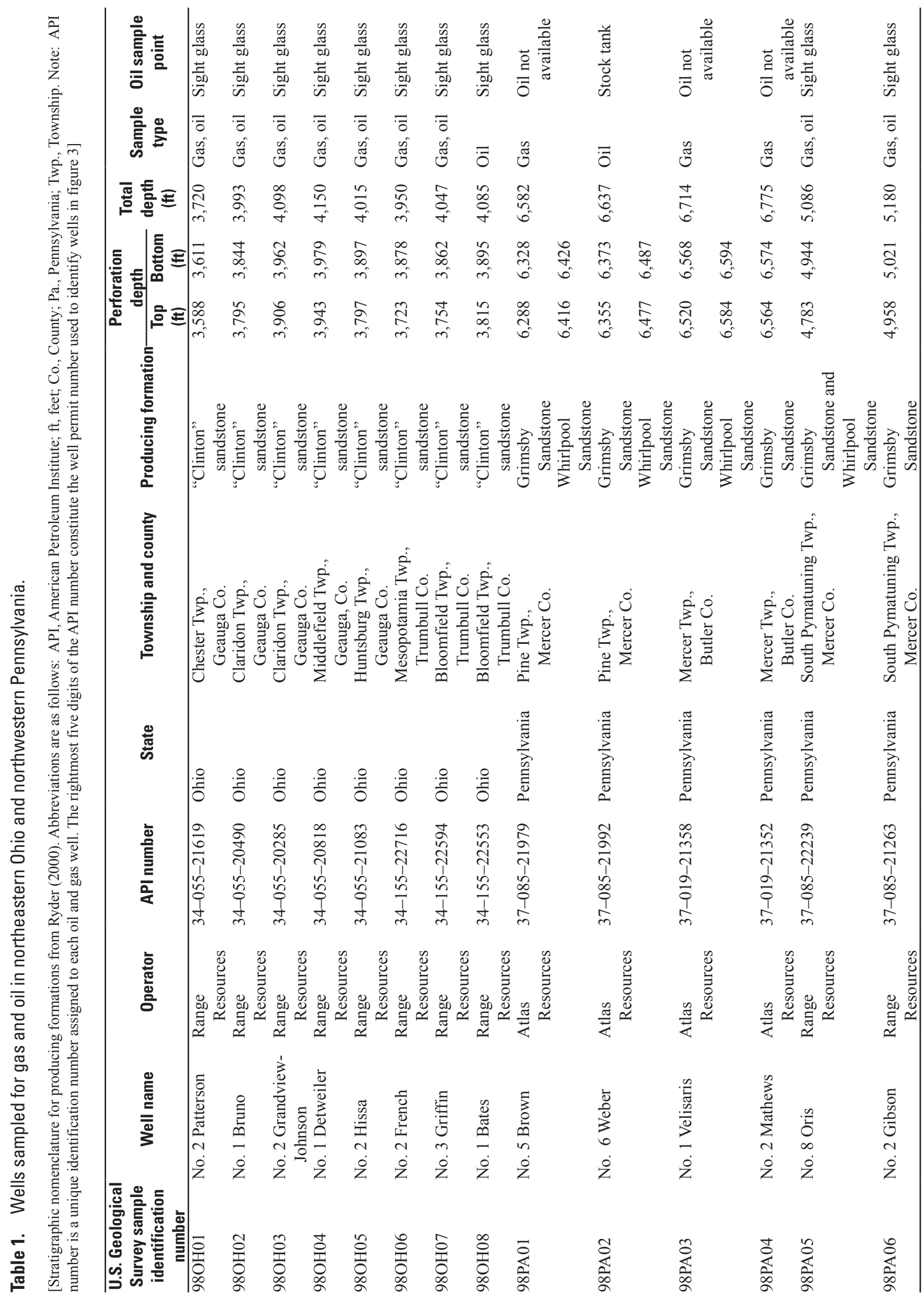




\section{Sampling and Analytical Methods}

Most of the oil and gas samples for this study were obtained, with the assistance of the operating company's field personnel, from the wellhead or from the oil and gas separator of individual wells. One oil sample was taken from the stock tank at the well site. Gas was sampled at the pressure-gauge port on the production tubing using evacuated stainless-steel cylinders supplied by Isotech Laboratories, Inc., Champaign, Ill. Oil was sampled, where possible, at the drain for the fluidlevel sight glass on the oil and gas separator. The oil is initially saturated with gas at the separator pressure and foams from exsolution of the gas as it exits the sight glass drain. One oil sample was bailed from the stock tank.

All samples were analyzed by standard methods. Natural gas samples were analyzed for molecular composition by gas chromatography and for stable isotopic composition by isotope-ratio mass spectrometry at Isotech Laboratories, Inc. Carbon isotopic composition was determined for methane $\left(\mathrm{C}_{1}\right)$, ethane $\left(\mathrm{C}_{2}\right)$, propane $\left(\mathrm{C}_{3}\right)$, and $n$-butane $\left(\mathrm{C}_{4}\right)$; hydrogen isotopic composition was determined for methane; and nitrogen isotopic composition was determined for molecular nitrogen. Carbon $\left({ }^{13} \mathrm{C}\right)$ isotope ratios are reported in standard parts per thousand (per mil) notation relative to the Vienna Peedee belemnite (VPDB) standard, and hydrogen $\left({ }^{2} \mathrm{H}\right)$ isotope ratios are reported relative to the Vienna standard mean ocean water (VSMOW) for both gases and oils. Nitrogen $\left({ }^{15} \mathrm{~N}\right)$ isotope ratios are reported relative to atmospheric nitrogen.

The samples of crude oil were analyzed by the U.S. Geological Survey (Denver, Colo.). The American Petroleum Institute (API) gravity (equivalent to density) of the crude oil samples was determined gravimetrically using the API standard method. Oils were fractionated by dilution in $n$-heptane to remove asphaltenes. A concentrate of the solution was further fractionated by column chromatography on silica gel by selective elution with heptane, benzene, and benzene-methanol $(1: 1$ volume-to-volume $(\mathrm{v} / \mathrm{v})$ concentration ratio) to collect the saturated hydrocarbon, aromatic hydrocarbon, and resin (nitrogen-, sulfur-, and oxygen- (NSO-) bearing compounds) fractions, respectively. The carbon stable-isotope composition of an aliquot (a representative sample) of the saturated and aromatic hydrocarbon fractions was determined on a Micromass Optima isotope-ratio mass-spectrometry system.

Gas chromatography of the whole oil and of the saturated and aromatic hydrocarbon fractions was performed with a Hewlett Packard (HP) Model 6890 (HP6890) gas chromatograph with a 60 meter $(\mathrm{m}) \times 0.32$ millimeter $(\mathrm{mm}) \times 0.25$ micrometer $(\mu \mathrm{m}) \mathrm{HP}-1$ fused silica capillary column and a flame-ionization detector (FID). The oven was programmed from $50^{\circ} \mathrm{C}$ to $330^{\circ} \mathrm{C}$ at $4.5^{\circ} \mathrm{C}$ per minute and held isothermally at $330^{\circ} \mathrm{C}$ for $15 \mathrm{~min}-$ utes with the helium carrier-gas-flow rate of 35 centimeters per second $(\mathrm{cm} / \mathrm{s})$. Gas chromatography-mass spectrometry (GCMS) of the saturated hydrocarbon fraction of one oil sample was performed with a HP6890-JEOL GCMate system in selective ionmonitoring mode to identify steranes and terpanes in the fraction.

\section{Results}

\section{Natural Gases}

The molecular and isotopic compositions of natural gas samples from 12 wells are presented in table 2. All 12 samples were rich in methane (between 76 and 90 mole percent), with low concentrations of hydrocarbons that have more than four carbon atoms. All samples contained a trace of helium and between 2.01 and 4.55 mole percent nitrogen. A trace of hydrogen was detected in 8 of the 12 samples. The gas compositions of these 12 samples were consistent with those reported for the "Clinton" sandstone in Ohio by the U.S. Bureau of Mines (Moore, 1982).

The carbon isotopic composition of methane, ethane, propane, and $n$-butane in the samples ranges from about 7 to 12 per mil for each component. In 8 of 12 wells, the carbon isotopic composition of methane, ethane, propane, and $n$-butane (where analysis was possible) become respectively heavier, as is normally expected (Chung and others, 1988); however, in 4 wells, the carbon isotopic composition of methane, ethane, propane, and $n$-butane (where analysis was possible) show several combinations resulting in reversal in the normal trend (see the No. 5 Brown well in table 2). The variation in the hydrogen isotopic composition of methane is about 50 per mil and the variation in the nitrogen isotopic composition is about 4 per mil. The carbon-dioxide content in the samples was so low (0.04 mole percent or less) that the carbon isotopic composition of this constituent could not be determined.

Natural gas samples from the "Clinton" sandstone and the Grimsby and Whirlpool Sandstones of the Medina Group, from both this study and Burruss and Ryder (this volume, chap. G.7), are thermogenic in origin based on a plot of the isotopic composition on a Schoell (1983) diagram (fig. 4). The $\delta^{13} \mathrm{C}$ methane and $\delta^{2} \mathrm{H}$ methane values for each sample define a straight line that indicates that the gases became isotopically heavier with depth of production (fig. 4). For example, $\delta^{13} \mathrm{C}$ methane values range from -41.98 per mil in the No. 2 Patterson well (about 3,600 $\mathrm{ft}$ to the gas production) near the northwest end of section $D-D^{\prime}$ (Keighin, 1998) to -33.97 per mil in the No. 2 Mathews well (about 6,570 ft) near the southeast end. Isotopic compositions of additional Lower Silurian gases from northwestern Pennsylvania (Laughrey and Baldassare, 1998) and Lower Silurian gases from New York (Jenden and others, 1993) also fit the trend defined in figure 4. Natural gases in the basin-center part of the regional accumulation are differentiated from natural gases in the hybrid-conventional part based on their position relative to the $\delta^{13} \mathrm{C}$ methane value of -37.0 per mil (fig. 4).

\section{Crude Oils}

Bulk parameters and selected molecular parameters of the crude oil samples are listed in table 3 . The API gravity of 8 of 
Table 2. Molecular and isotopic composition of gas samples.

[Carbon $\left({ }^{13} \mathrm{C}\right.$ ) isotope ratios are reported in standard parts per thousand (per mil) notation relative to the Vienna Peedee belemnite (VPDB) standard. Hydrogen $\left({ }^{2} \mathrm{H}\right)$ isotope ratios are reported relative to the Vienna standard mean ocean water (VSMOW) for both gases and oils. Nitrogen $\left({ }^{15} \mathrm{~N}\right)$ isotope ratios are reported relative to atmospheric nitrogen. Abbreviations are as follows: nd, not detected;,$+ \mathrm{C}_{6}$ and higher hydrocarbons]

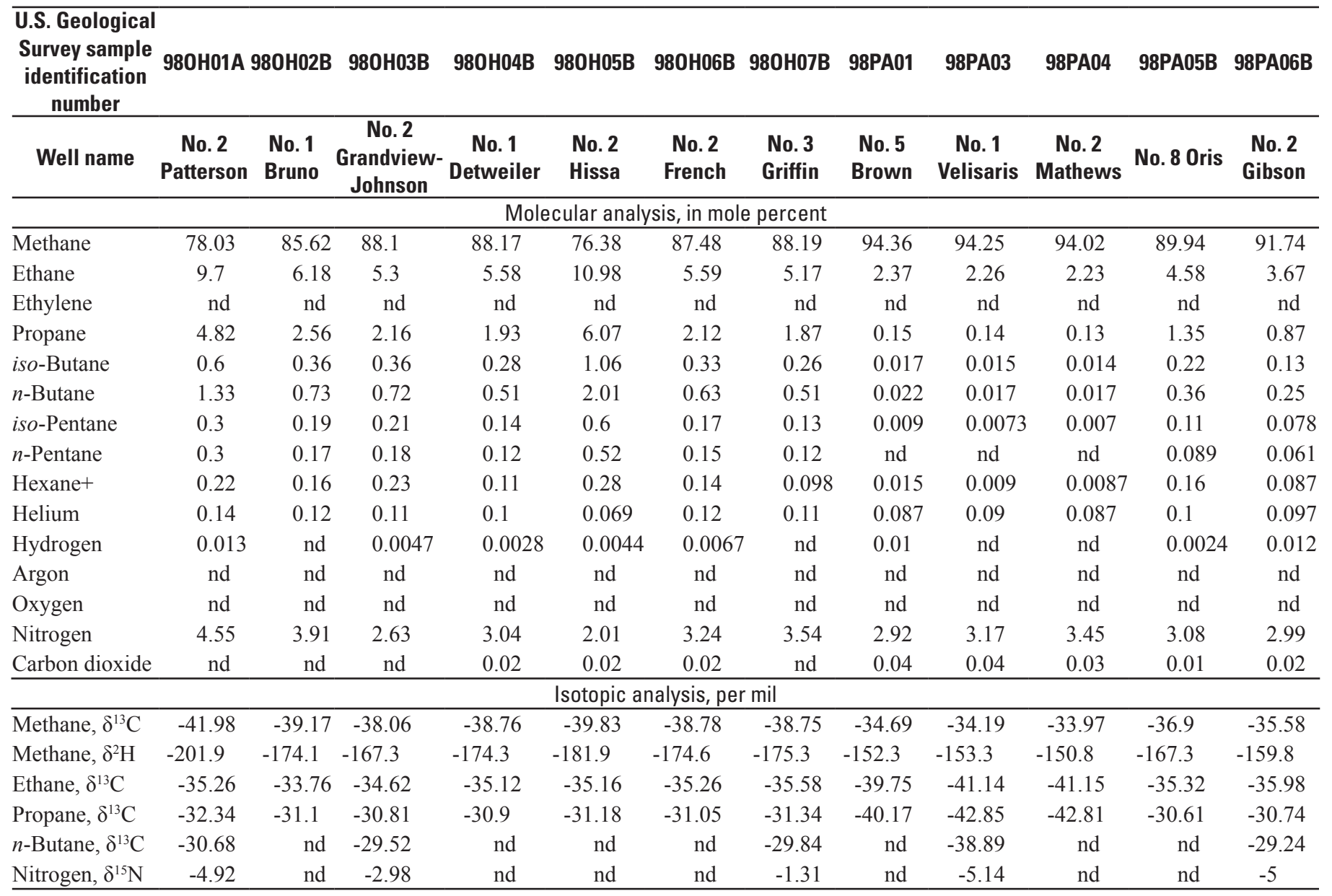

the 11 samples was $40^{\circ}$ or greater. One of the three exceptions, the sample from the No. 6 Weber well, with an API gravity of $39.9^{\circ}$, was bailed from the top of the stock tank instead of being collected at the separator. The oils were uniformly high (84 to 92 weight percent) in saturated hydrocarbons and contained 12 percent or less of aromatic hydrocarbons. Carbon isotopic compositions of the saturated and aromatic hydrocarbon fractions showed small ranges of 0.8 per mil and 1.0 per mil, respectively.

Gas chromatograms of the whole oil, the saturated hydrocarbon fraction, and the aromatic hydrocarbon fraction for samples from the 11 wells are shown in figures $5 A, 5 B$, and $5 C$, respectively, through figures $15 A, 15 B$, and $15 C$. The saturated hydrocarbon gas chromatograms have characteristics similar to oils from the "Clinton" sandstone reported by Cole and others (1987). Molecular parameters derived from the gas chromatograms of the saturated hydrocarbon fractions are listed in table 4 . All whole-oil gas chromatograms, except the one from the No. 6 Weber well, show a full spectrum of $n$-alkanes from $n$ - $\mathrm{C}_{10}$ to $n$ - $\mathrm{C}_{30+}$. The whole oil chromatogram for the sample from the No. 6 Weber well shows depletion in the low-carbon-number range (less than $n-\mathrm{C}_{10}$ ), which suggests that the lighter $n$-alkanes were lost by evaporation. Two types of $n$-alkane distributions and one intermediate type are recorded by gas chromatograms of the saturated hydrocarbon fraction. Of the 11 saturated hydrocarbon chromatograms (including the one for the No. 6 Weber well sample), 6 show a broad spectrum of $n$-alkanes whose peak heights progressively diminish toward the higher carbon numbers (fig. $8 B$ ); 2 chromatograms have a bimodal distribution of $n$-alkanes that peak at about $n$ - $\mathrm{C}_{14}$ and $n$ - $\mathrm{C}_{24}$ (fig. $6 \mathrm{~B}$ ); and 3 chromatograms show a broad spectrum of $n$-alkanes whose peak heights progressively diminish toward the higher carbon numbers but show a secondary peak at $n-\mathrm{C}_{24}$ (for example, fig. $11 B$ ). The three types of $n$-alkane distributions show a modest oddcarbon-number preference and the presence of isoprenoids. The pristine-to-phytane (pr:ph) ratios are given as quotients in table 4 and range from 1.31 to 2.01 .

Text continues on page 32 . 


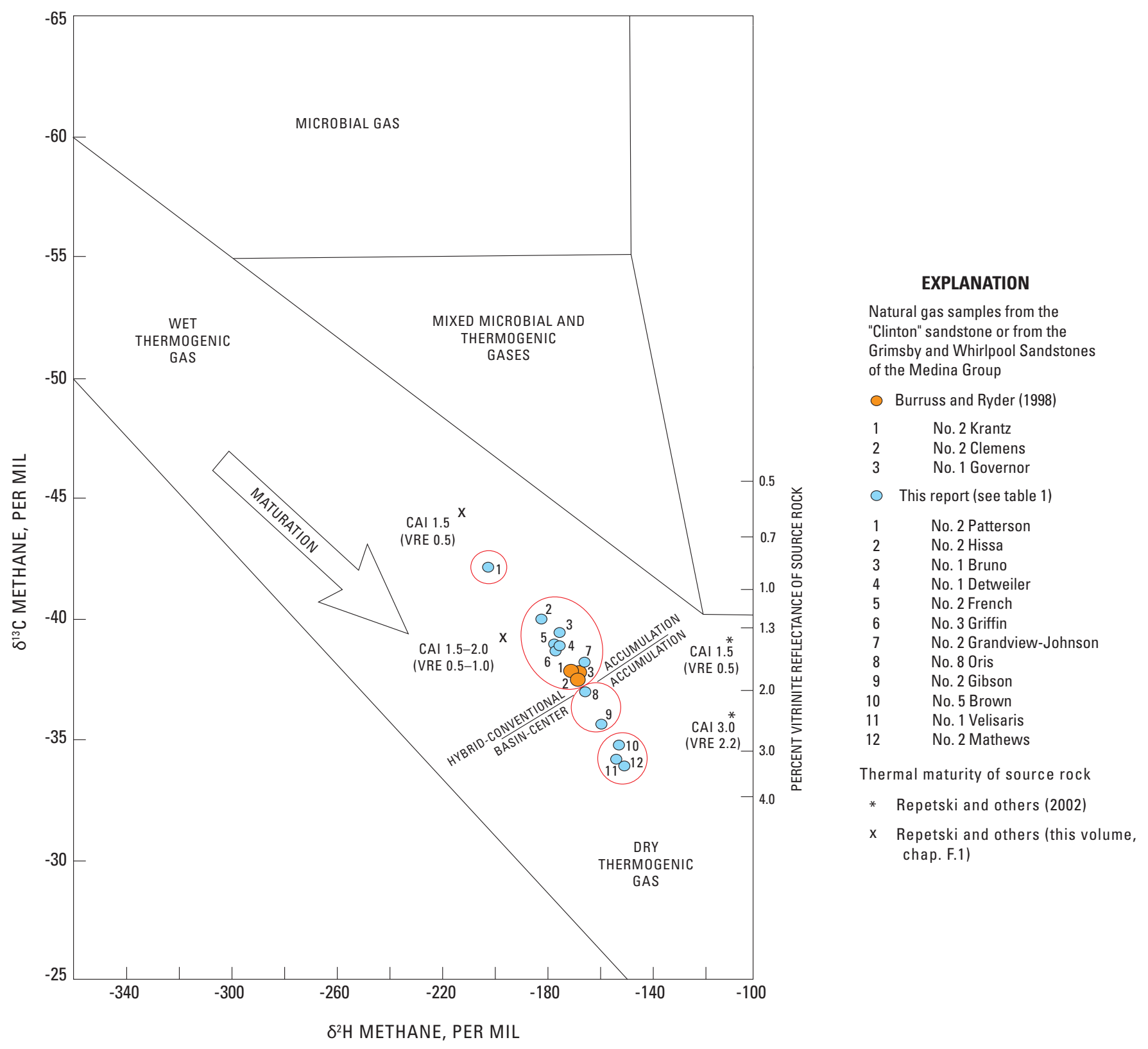

Figure 4. Schoell (1983) diagram showing the isotopic composition of selected natural gases in the Lower Silurian regional oil and gas accumulation. A scale devised by Jenden and others (1993) for estimating the approximate vitrinite reflectance $\left(\% R_{0}\right)$ of the source rock that generated the gas is attached to the right side of the diagram. Also shown are the conodont alteration index (CAI) thermal maturity values for Middle Ordovician carbonate rocks located near the proposed Middle Ordovician Utica Shale source rock. 
Table 3. Properties of the whole crude oil and crude oil fractions.

[Carbon $\left({ }^{13} \mathrm{C}\right.$ ) isotope ratios are reported in standard parts per thousand (per mil) notation relative to the Vienna Peedee belemnite (VPDB) standard. Abbreviations are as follows: API, American Petroleum Institute]

\begin{tabular}{|c|c|c|c|c|c|c|c|c|}
\hline \multirow{2}{*}{$\begin{array}{c}\text { U.S. Geological } \\
\text { Survey sample } \\
\text { identification } \\
\text { number. }\end{array}$} & \multirow[b]{2}{*}{ Well name } & \multirow{2}{*}{$\begin{array}{l}\text { API gravity } \\
\text { (degrees) }\end{array}$} & \multicolumn{4}{|c|}{ Petroleum fractions (weight percent) } & \multicolumn{2}{|c|}{$\begin{array}{l}\text { Isotopic composition (per } \\
\text { mil) }\end{array}$} \\
\hline & & & $\begin{array}{c}\text { Saturated } \\
\text { hydrocarbons }\end{array}$ & $\begin{array}{l}\text { Aromatic hy- } \\
\text { drocarbons }\end{array}$ & $\begin{array}{l}\text { Nitrogen-, sulfur-, } \\
\text { and oxygen-bear- } \\
\text { ing organics }\end{array}$ & Asphaltenes & $\begin{array}{c}\text { Saturated } \\
\text { hydrocarbons } \\
\left(\delta^{13} \mathrm{C}\right)\end{array}$ & $\begin{array}{l}\text { Aromatic hy- } \\
\text { drocarbons } \\
\left(\delta^{13} \mathrm{C}\right)\end{array}$ \\
\hline 98OH01B & No. 2 Patterson & 42.8 & 84.46 & 10.72 & 2.91 & 1.90 & -30.22 & -29.74 \\
\hline $98 \mathrm{OH} 02 \mathrm{~A}$ & No. 1 Bruno & 41.4 & 85.21 & 12.10 & 2.58 & 0.11 & -30.08 & -29.40 \\
\hline 98OH04A & No. 1 Detweiler & 43.8 & 86.85 & 9.04 & 3.55 & 0.56 & -29.95 & -29.01 \\
\hline $98 \mathrm{OH} 05 \mathrm{~A}$ & No. 2 Hissa & 42.8 & 86.71 & 8.72 & 4.08 & 0.49 & -30.17 & -29.37 \\
\hline 98OH06A & No. 2 French & 43.0 & 84.40 & 11.36 & 3.55 & 0.70 & -30.09 & -29.16 \\
\hline 98OH07A & No. 3 Griffin & 33.8 & 88.03 & 9.26 & 2.43 & 0.29 & -30.08 & -29.23 \\
\hline 98PA06A & No. 2 Gibson & 38.8 & 92.96 & 4.27 & 2.37 & 0.39 & -29.47 & -28.80 \\
\hline
\end{tabular}

Table 4. Properties of the saturated hydrocarbon fraction of the crude oils.

[These properties were calculated on the basis of peak area from analyses performed on April 1999. Abbreviations are as follows: pr, pristane; ph, phytane; $n$-alk, $n$-alkanes in the total saturated fraction, n.d., not determined. The condensate index (defined by Lewan and Buchardt, 1989) was calculated as the percent of $n-\mathrm{C}_{11}$ in $n-\mathrm{C}_{10}$ to $n-\mathrm{C}_{30}$. The carbon preference index, percent of $n$-alkanes in the total saturated fraction, and the condensate index were not calculated for the No. 3 Griffin oil sample]

\begin{tabular}{|c|c|c|c|c|c|c|c|}
\hline \multirow{2}{*}{$\begin{array}{c}\text { U.S. Geological } \\
\text { Survey Sample } \\
\text { identification } \\
\text { number }\end{array}$} & \multirow[b]{2}{*}{ Well name } & \multicolumn{6}{|c|}{ Saturated hydrocarbon characteristics } \\
\hline & & pr:ph & $\mathrm{pr} / \mathrm{n}-\mathrm{C}_{17}$ & $\mathrm{ph} / \mathrm{n}-\mathrm{C}_{18}$ & $\begin{array}{c}\text { Carbon } \\
\text { preference } \\
\text { index }\end{array}$ & $\begin{array}{c}n \text {-alk } \\
\text { (percent) }\end{array}$ & $\begin{array}{l}\text { Condensate } \\
\text { index }\end{array}$ \\
\hline 98OH01B & No. 2 Patterson & 1.33 & 0.38 & 0.33 & 1.07 & 7.73 & 9.72 \\
\hline $98 \mathrm{OH} 02 \mathrm{~A}$ & No. 1 Bruno & 1.35 & 0.41 & 0.34 & 0.96 & 17.93 & 5.49 \\
\hline $98 \mathrm{OH} 03 \mathrm{~A}$ & $\begin{array}{l}\text { No. } 2 \text { Grandview- } \\
\text { Johnson }\end{array}$ & 1.36 & 0.40 & 0.33 & 0.99 & 24.58 & 7.21 \\
\hline $98 \mathrm{OH} 04 \mathrm{~A}$ & No. 1 Detweiler & 1.36 & 0.41 & 0.34 & 1.00 & 10.21 & 9.82 \\
\hline $98 \mathrm{OH} 05 \mathrm{~A}$ & No. 2 Hissa & 1.32 & 0.36 & 0.31 & 0.96 & 14.92 & 8.60 \\
\hline 98OH06A & No. 2 French & 1.38 & 0.38 & 0.32 & 1.04 & 17.95 & 10.81 \\
\hline 98OH07A & No. 3 Griffin & 1.31 & 0.27 & 0.23 & n.d. & n.d. & n.d. \\
\hline 98OH08 & No. 1 Bates & 1.31 & 0.43 & 0.38 & 1.06 & 6.35 & 9.51 \\
\hline 98РA02 & No. 6 Weber & 1.44 & 0.40 & 0.38 & 1.05 & 14.93 & 3.04 \\
\hline 98PA05A & No. 8 Oris & 1.94 & 0.29 & 0.19 & 1.03 & 18.74 & 8.23 \\
\hline 98PA06A & No. 2 Gibson & 2.01 & 0.28 & 0.17 & 1.02 & 20.40 & 5.99 \\
\hline
\end{tabular}




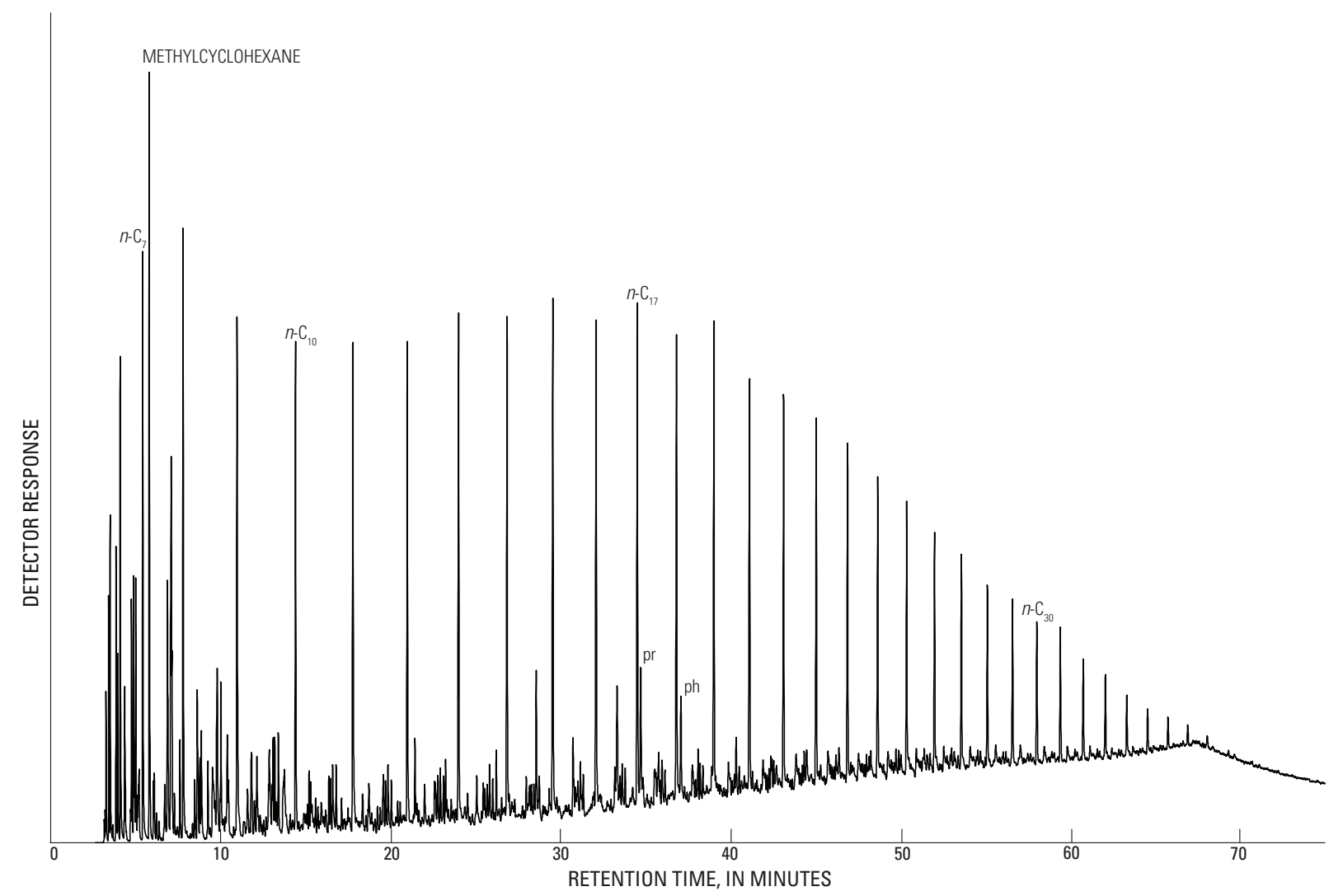

A

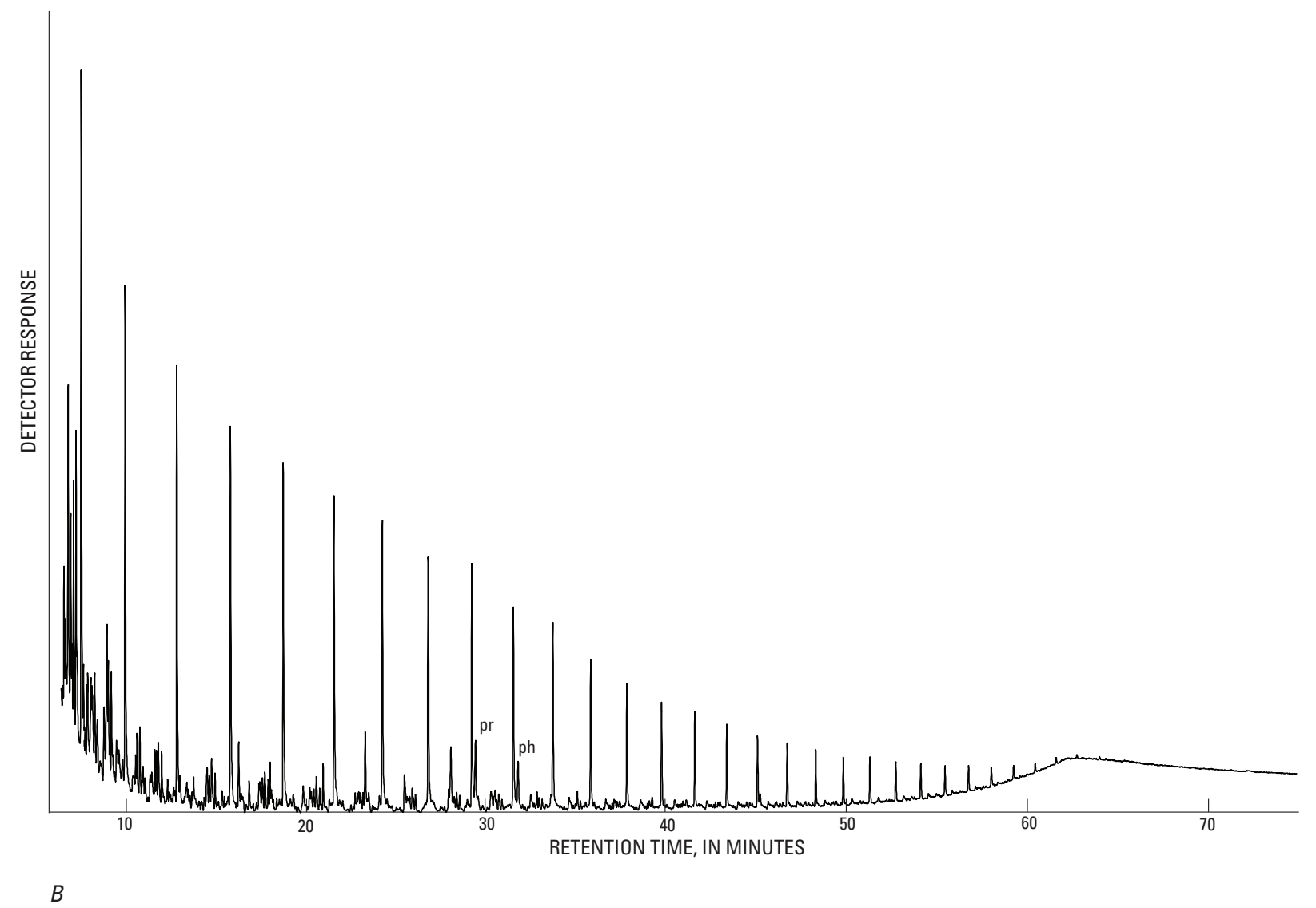




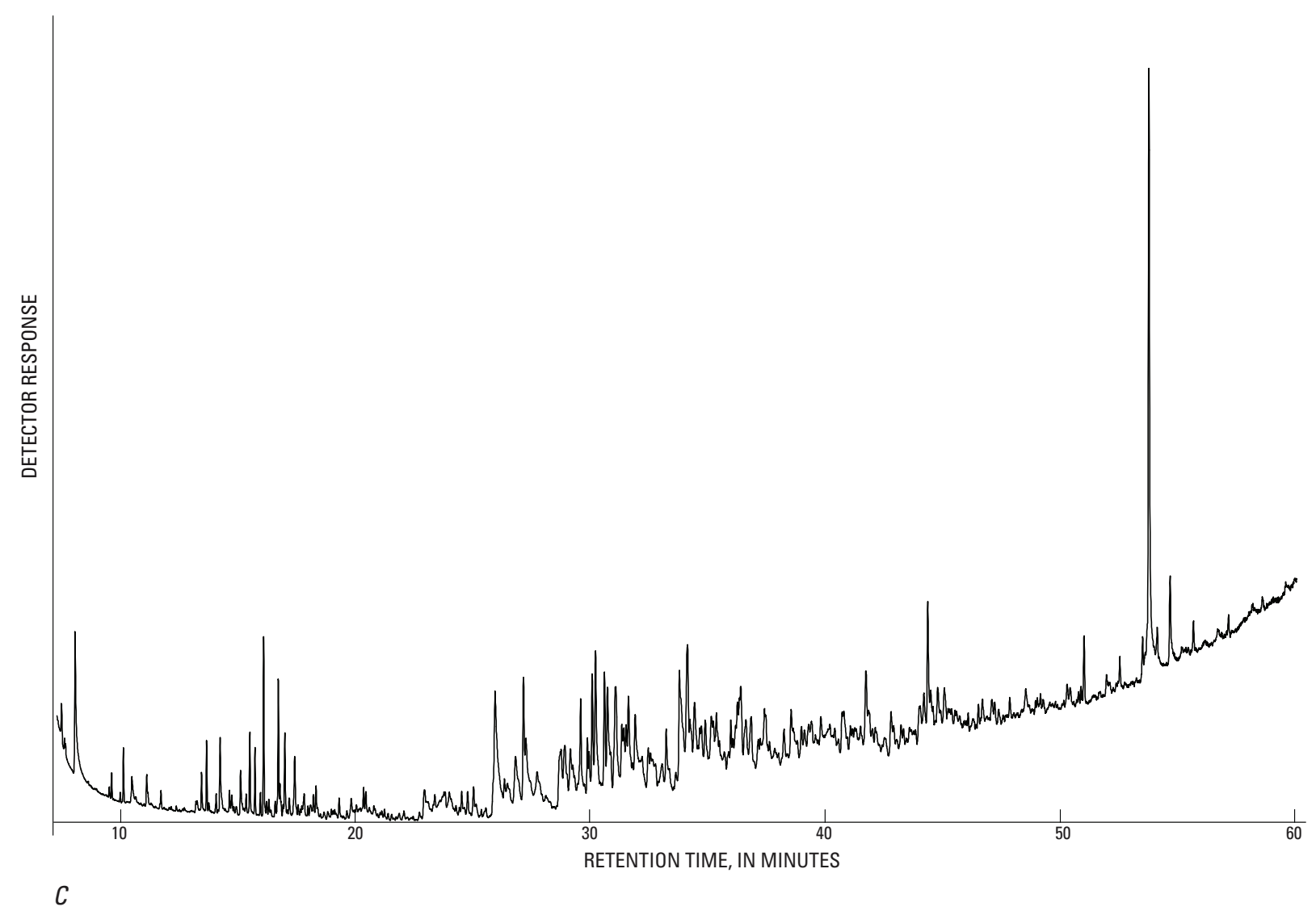

Figure 5 (facing page and this page). Gas chromatograms for sample 980H01B from the No. 2 Patterson well, Geauga County, Ohio. American Petroleum Institute (API) gravity is $42.8^{\circ}$. $A$, Whole-oil gas chromatogram, where $n$ - $C_{x}$ indicates a normal alkane with $x$ number of carbons. $B$, Saturated hydrocarbon fraction gas chromatogram. $C$, Aromatic hydrocarbon fraction gas chromatogram. Abbreviations are as follows: pr, pristane; ph, phytane. 


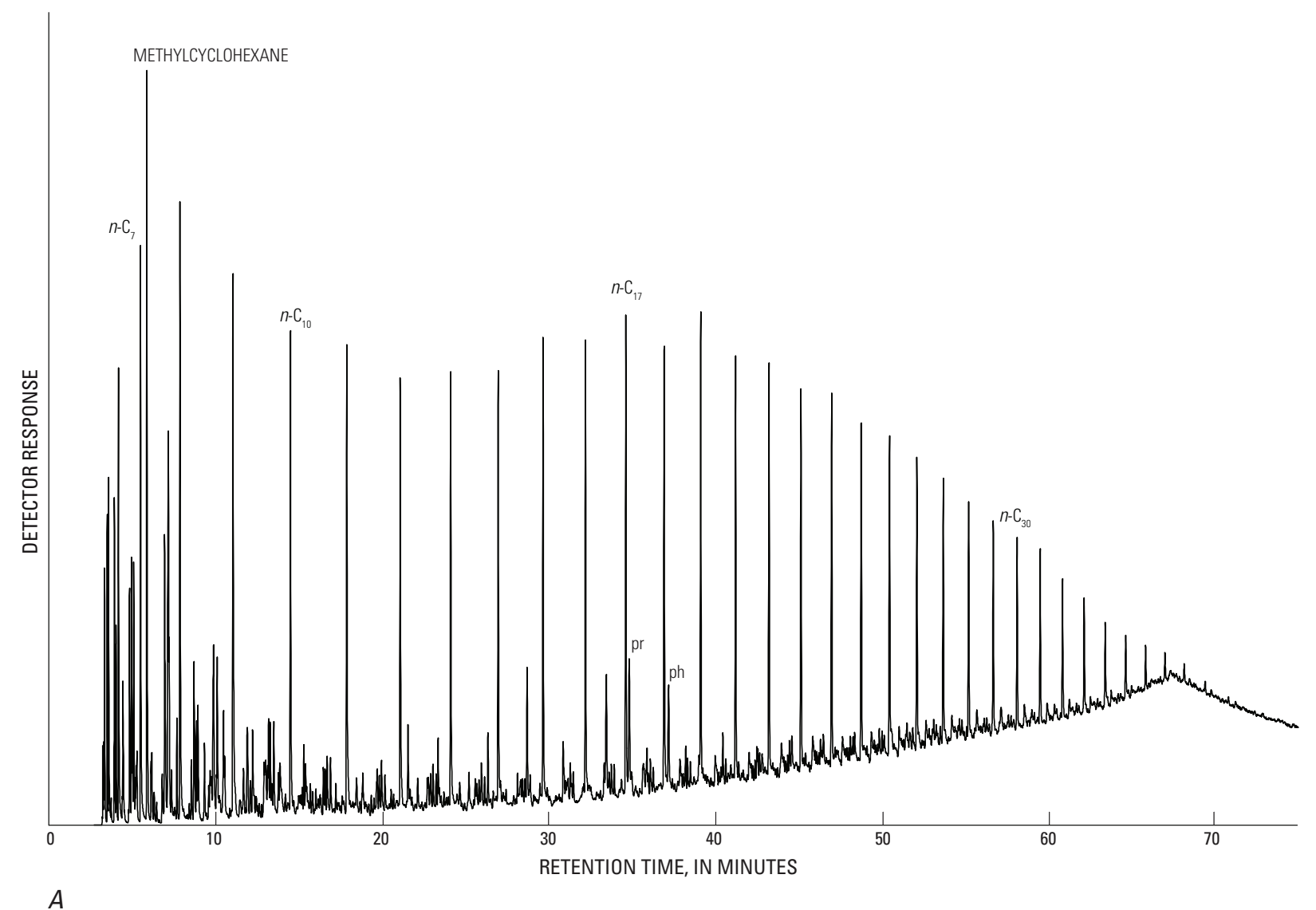

$A$

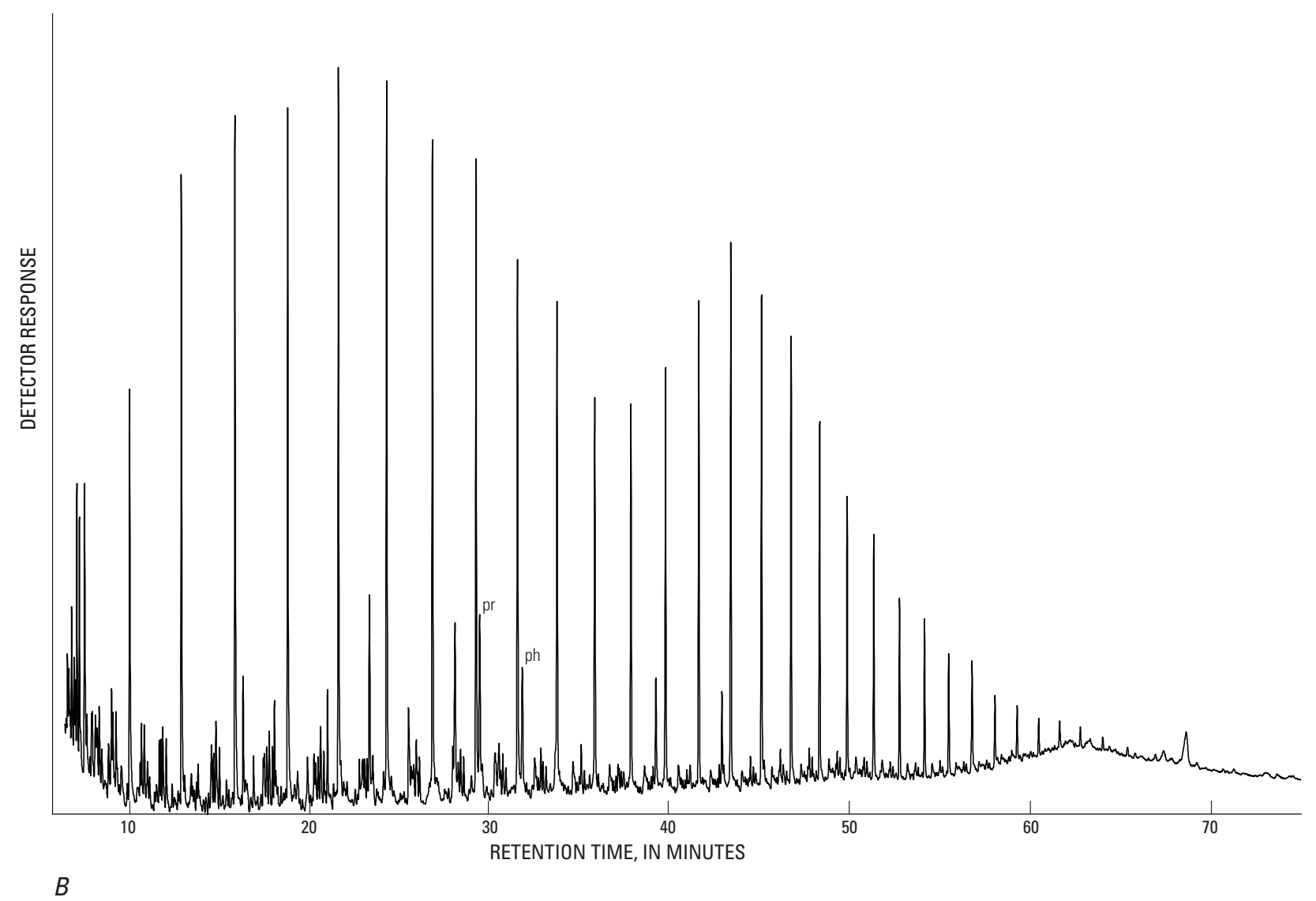




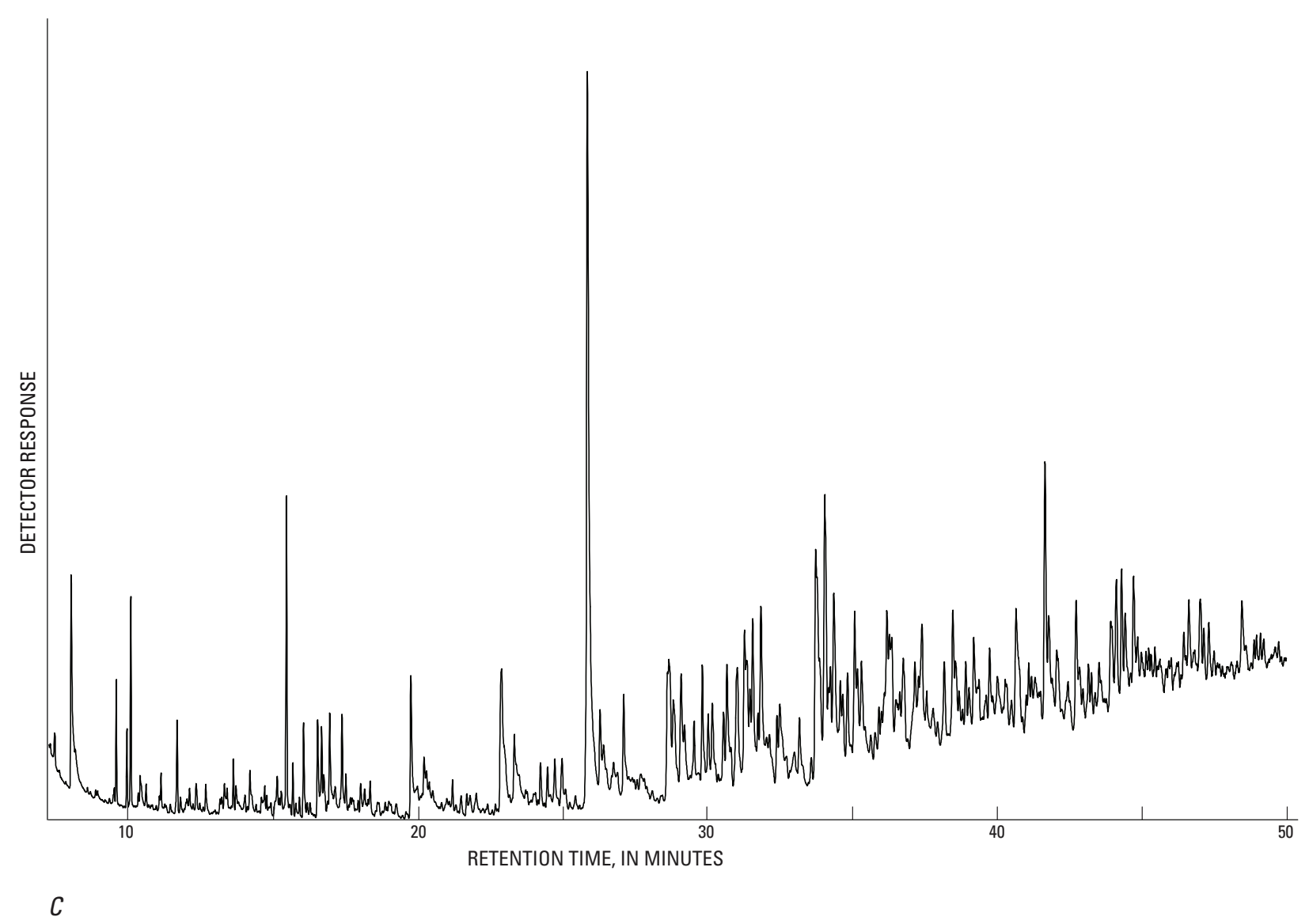

Figure 6 (facing page and this page). Gas chromatograms for sample 980H02A from the No. 1 Bruno well, Geauga County, Ohio. American Petroleum Institute (API) gravity is $41.4^{\circ}$. $A$, Whole-oil gas chromatogram, where $n-C_{x}$ indicates a normal alkane with $x$ number of carbons. $B$, Saturated hydrocarbon fraction gas chromatogram. $C$, Aromatic hydrocarbon fraction gas chromatogram. Abbreviations are as follows: pr, pristane; ph, phytane. 
Coal and Petroleum Resources in the Appalachian Basin
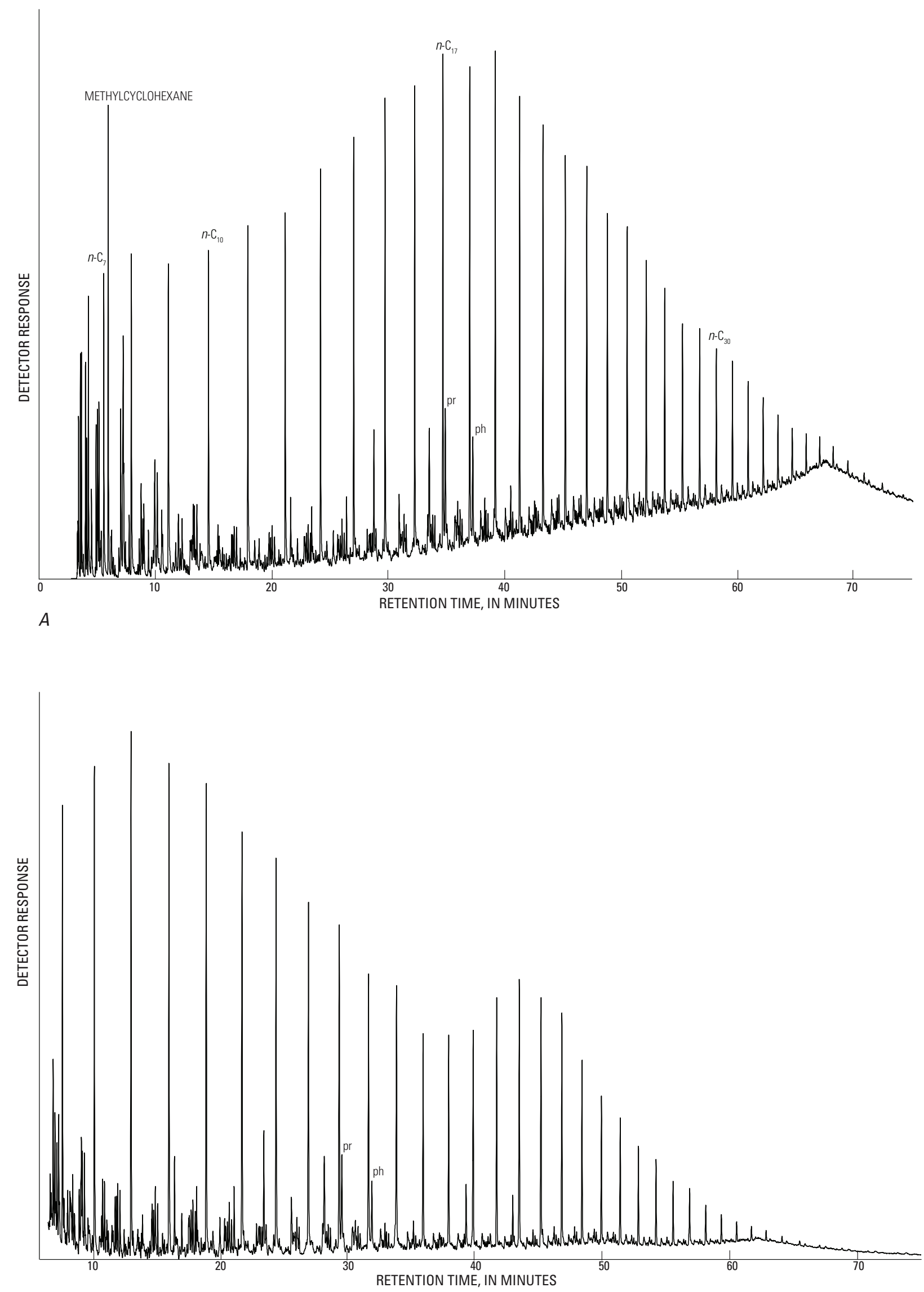


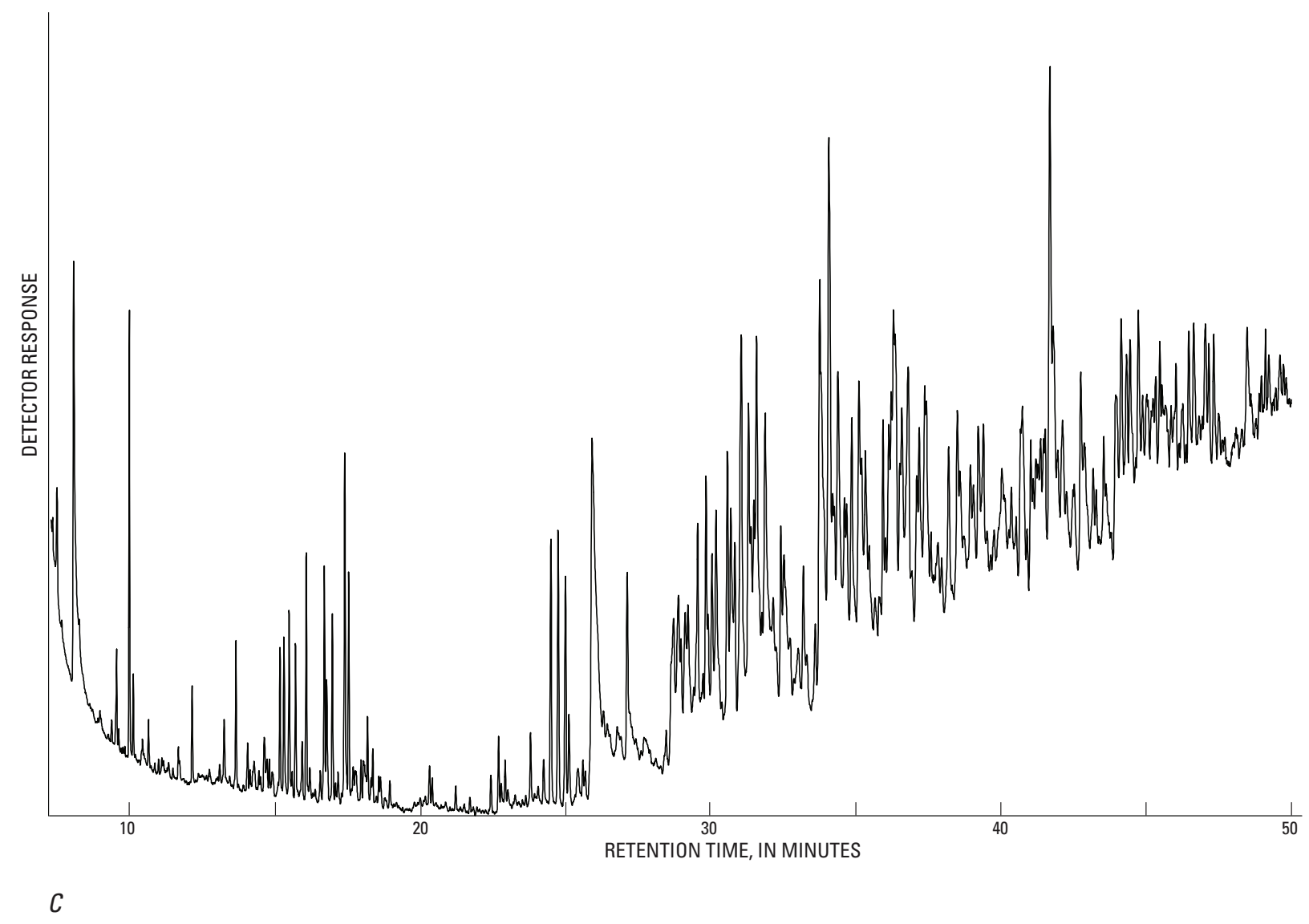

Figure 7 (facing page and this page). Gas chromatograms for sample 980H03A from the No. 2 Grandview-Johnson well, Geauga County, Ohio. American Petroleum Institute (API) gravity is $40.7^{\circ}$. A, Whole-oil gas chromatogram, where $n$ - $C_{x}$ indicates a normal alkane with $x$ number of carbons. $B$, Saturated hydrocarbon fraction gas chromatogram. $C$, Aromatic hydrocarbon fraction gas chromatogram. Abbreviations are as follows: pr, pristane; ph, phytane. 
16 Coal and Petroleum Resources in the Appalachian Basin

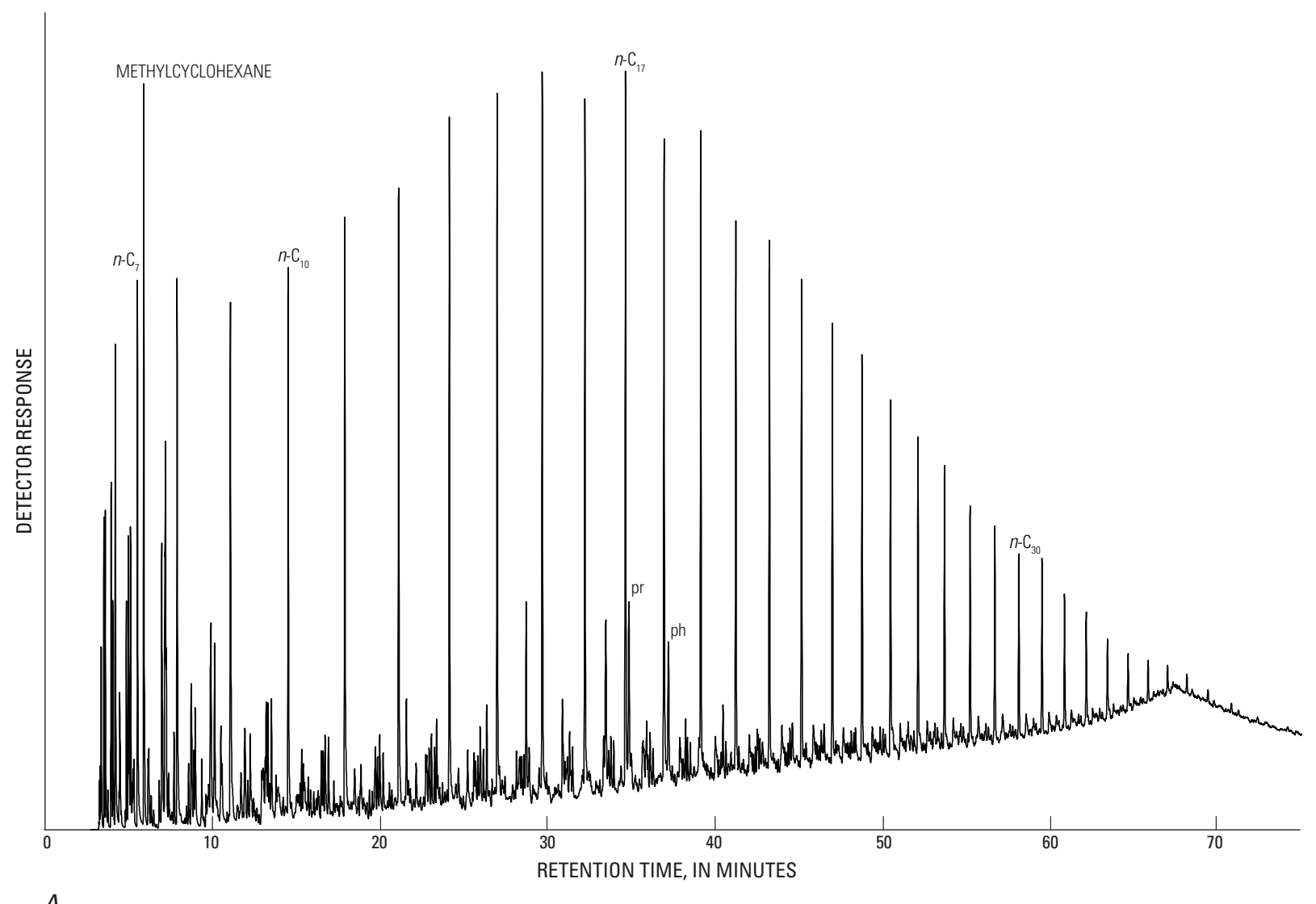

A

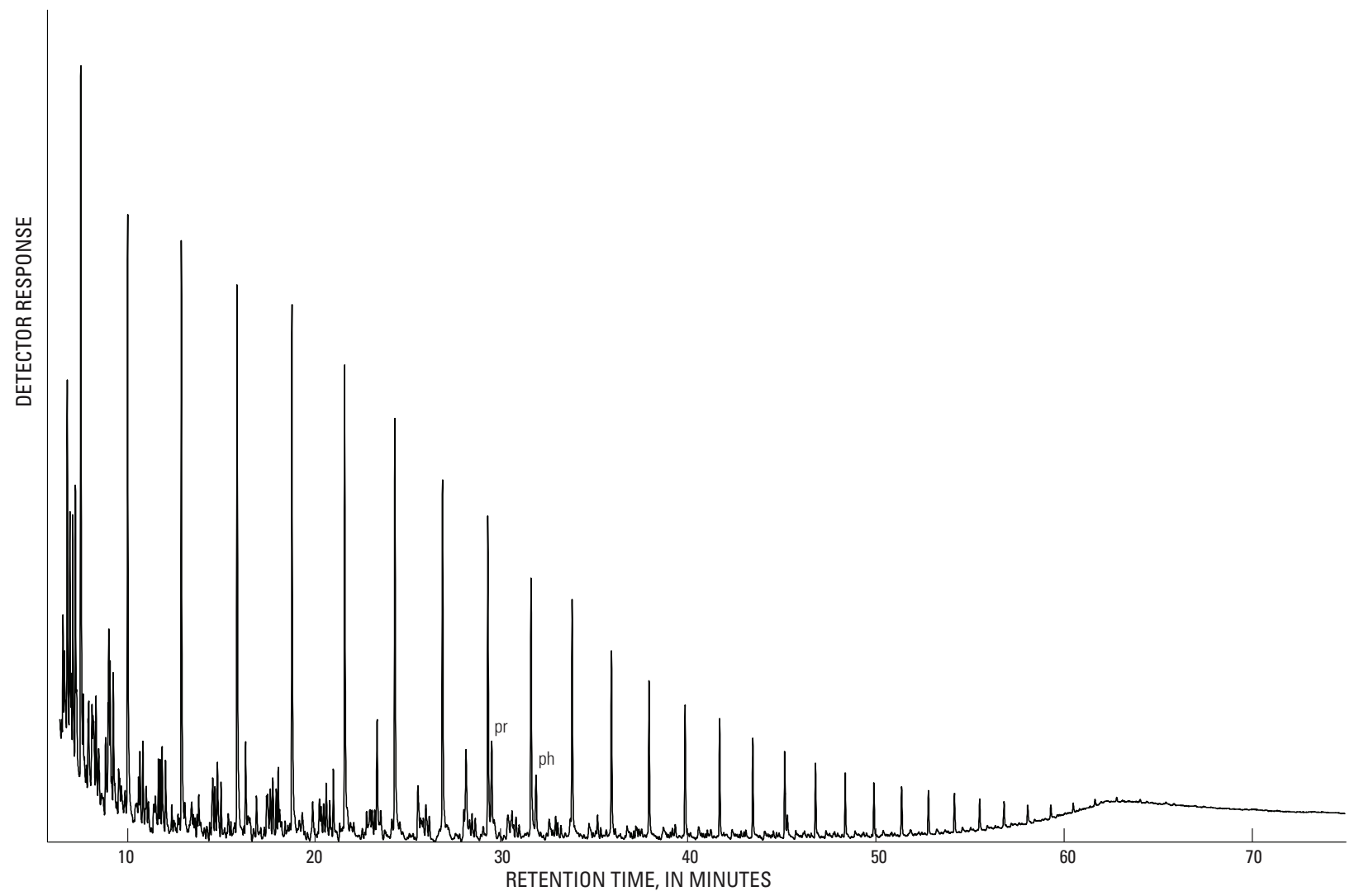

$B$ 


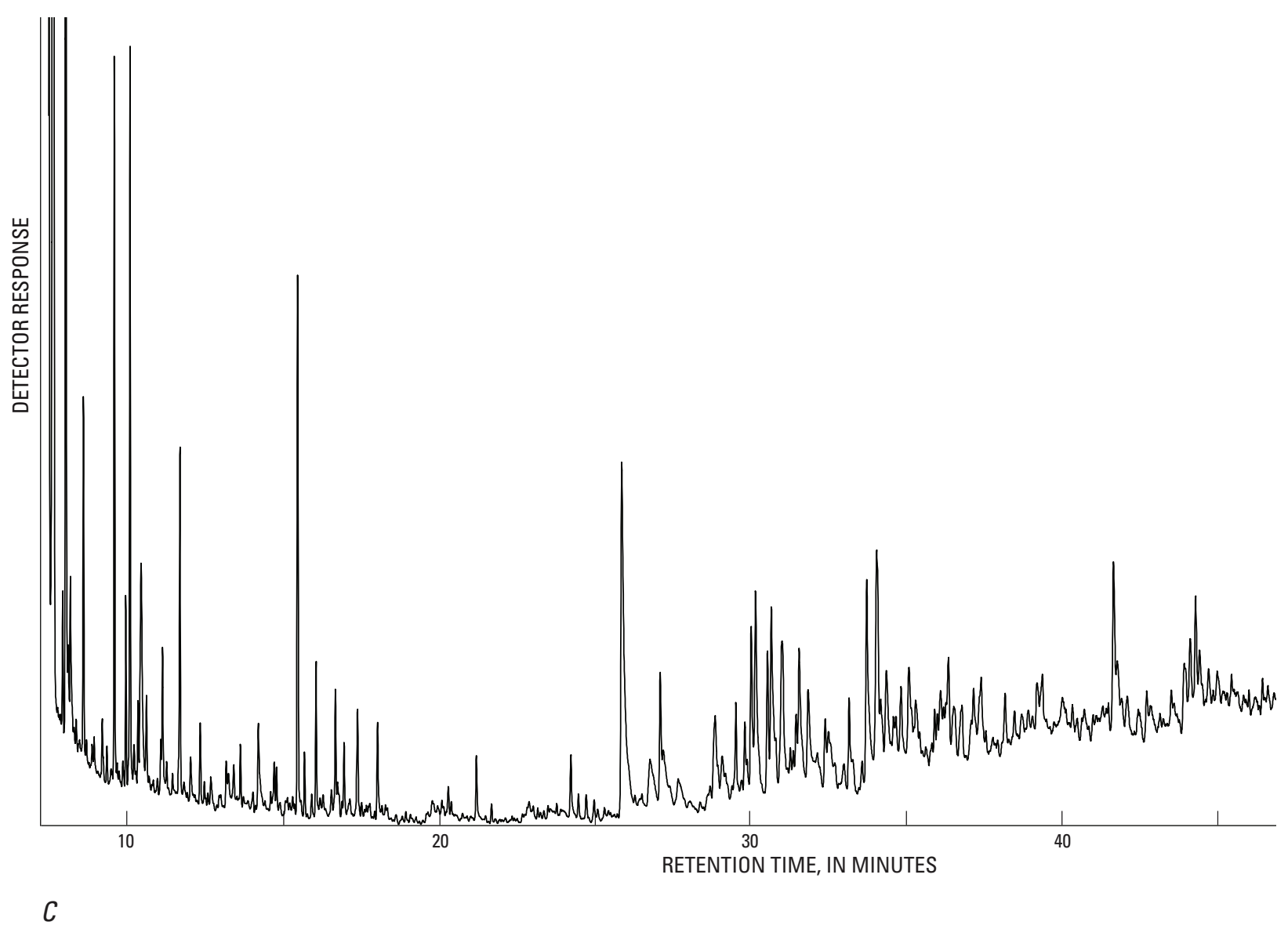

Figure 8 (facing page and this page). Gas chromatograms for sample 980H04A from the No. 1 Detweiler well, Geauga County, Ohio. American Petroleum Institute (API) gravity is $43.8^{\circ}$. A, Whole-oil gas chromatogram, where $n$ - $C_{x}$ indicates a normal alkane with $x$ number of carbons. $B$, Saturated hydrocarbon fraction gas chromatogram. $C$, Aromatic hydrocarbon fraction gas chromatogram. Abbreviations are as follows: pr, pristane; ph, phytane. 


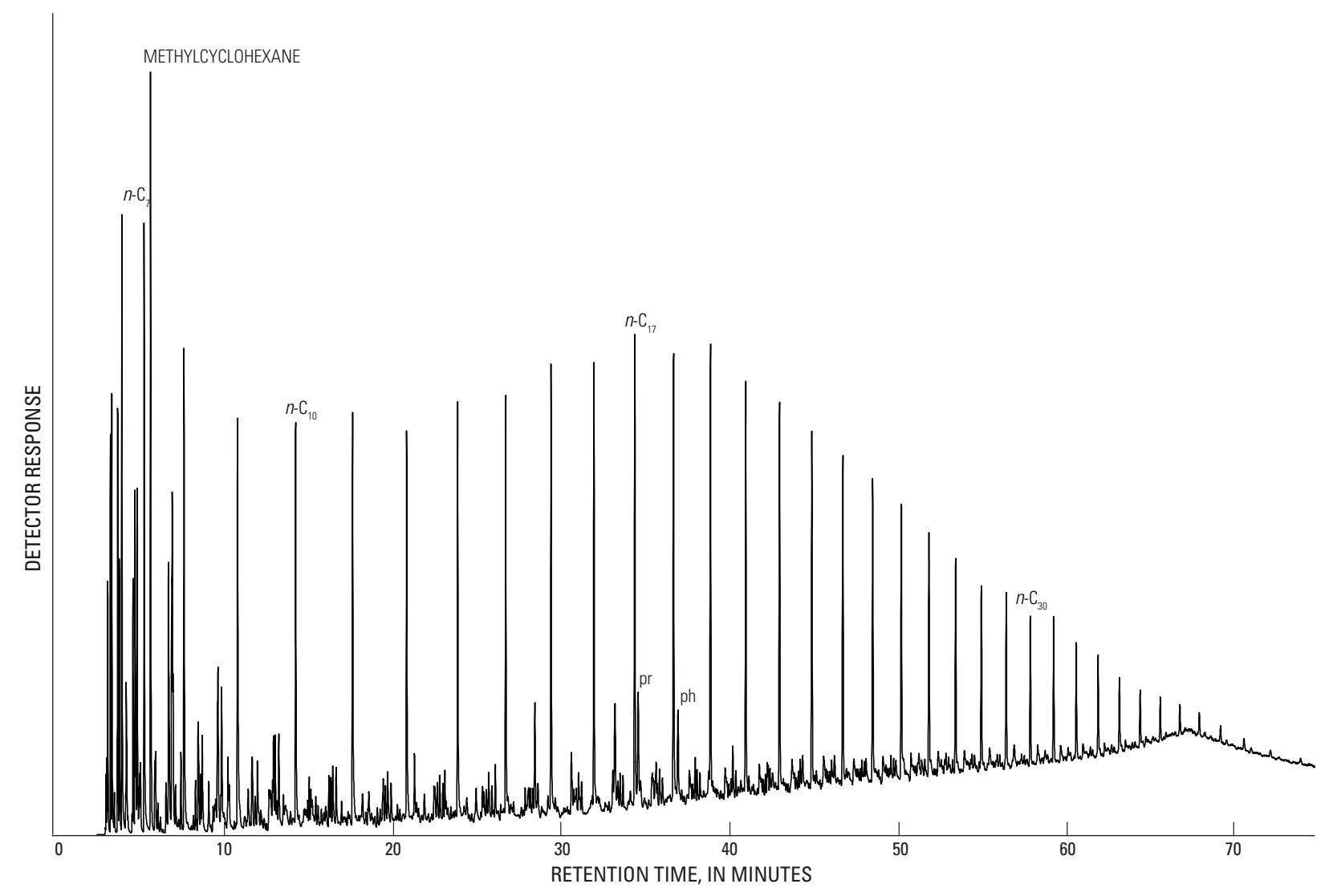

A

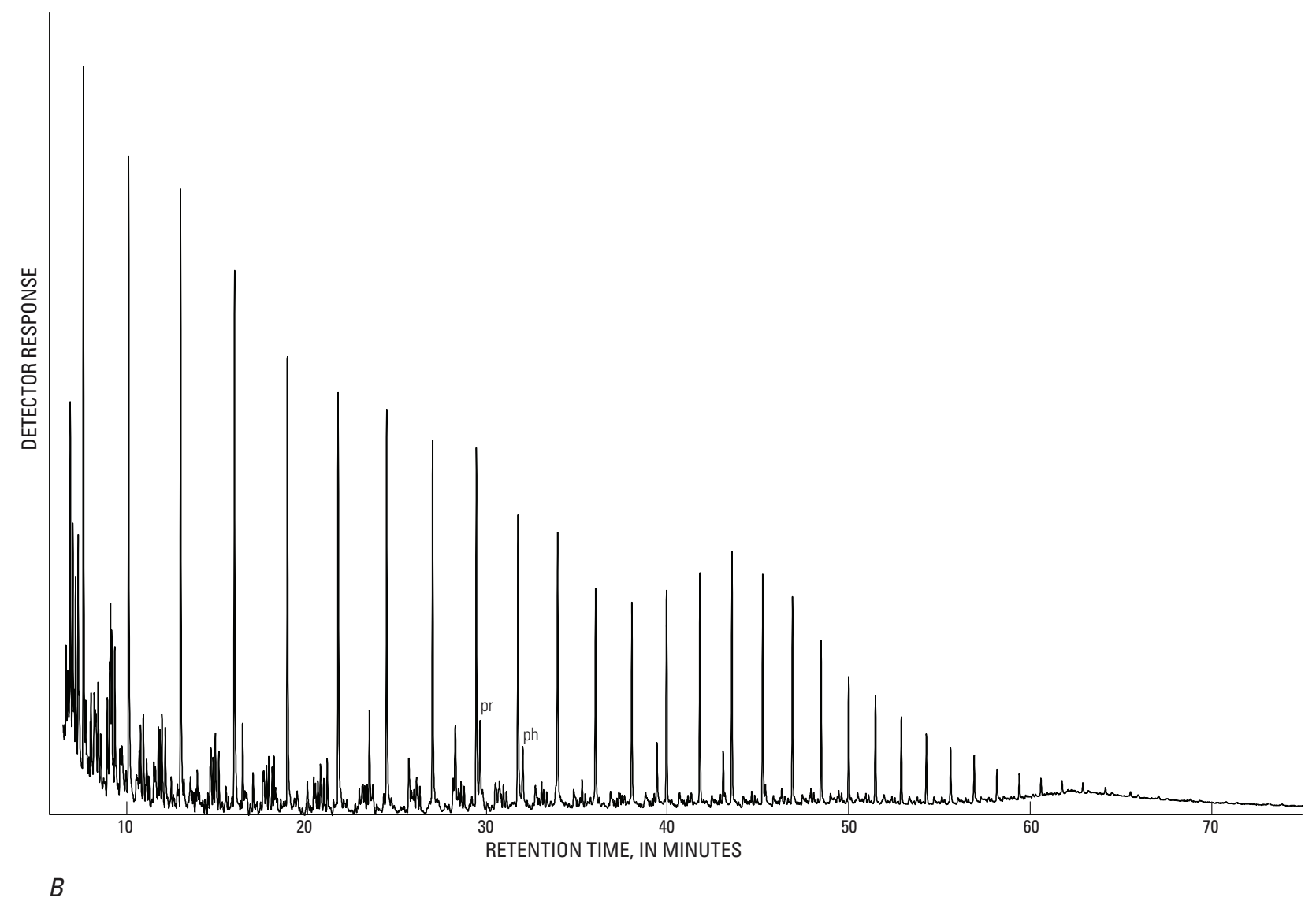




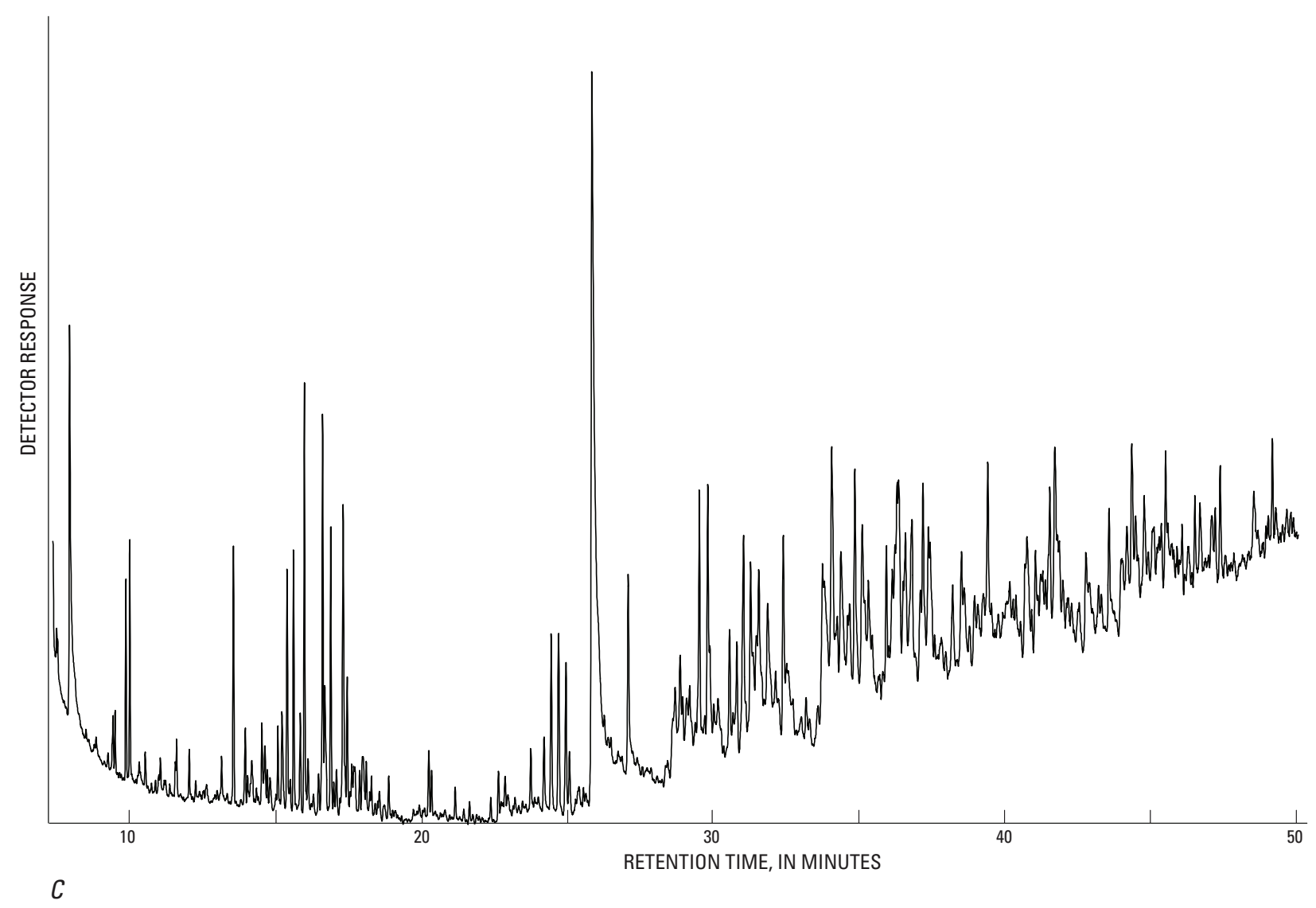

Figure 9 (facing page and this page). Gas chromatograms for sample 980H05A from the No. 2 Hissa well, collected from a separator that also serves the No. 1 Hissa well, Geauga County, Ohio. American Petroleum Institute (API) gravity is $42.8^{\circ}$. A, Whole-oil gas chromatogram, where $n$ - $C_{x}$ indicates a normal alkane with $x$ number of carbons. $B$, Saturated hydrocarbon fraction gas chromatogram. $C$, Aromatic hydrocarbon fraction gas chromatogram. Abbreviations are as follows: pr, pristane; ph, phytane. 


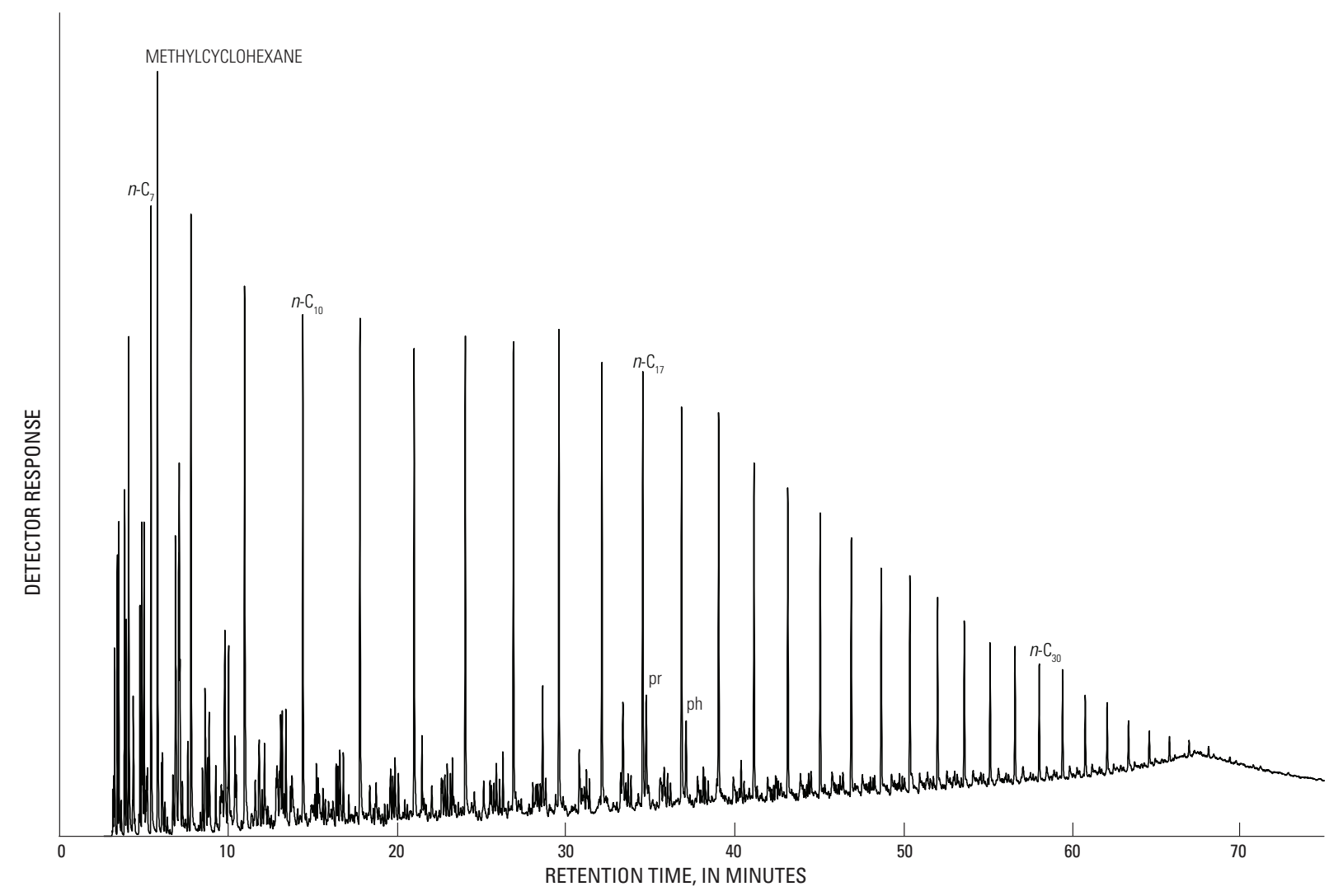

A

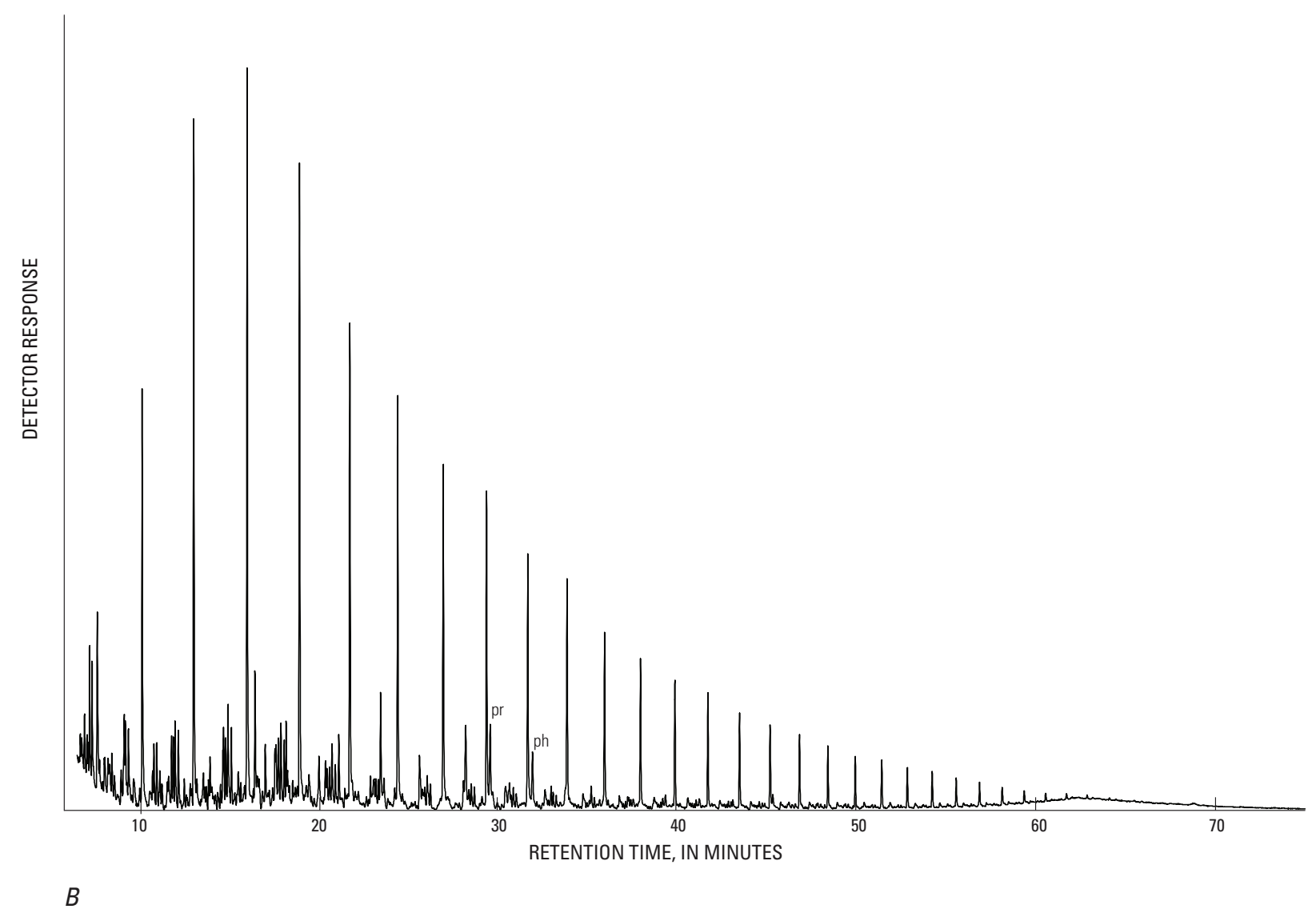




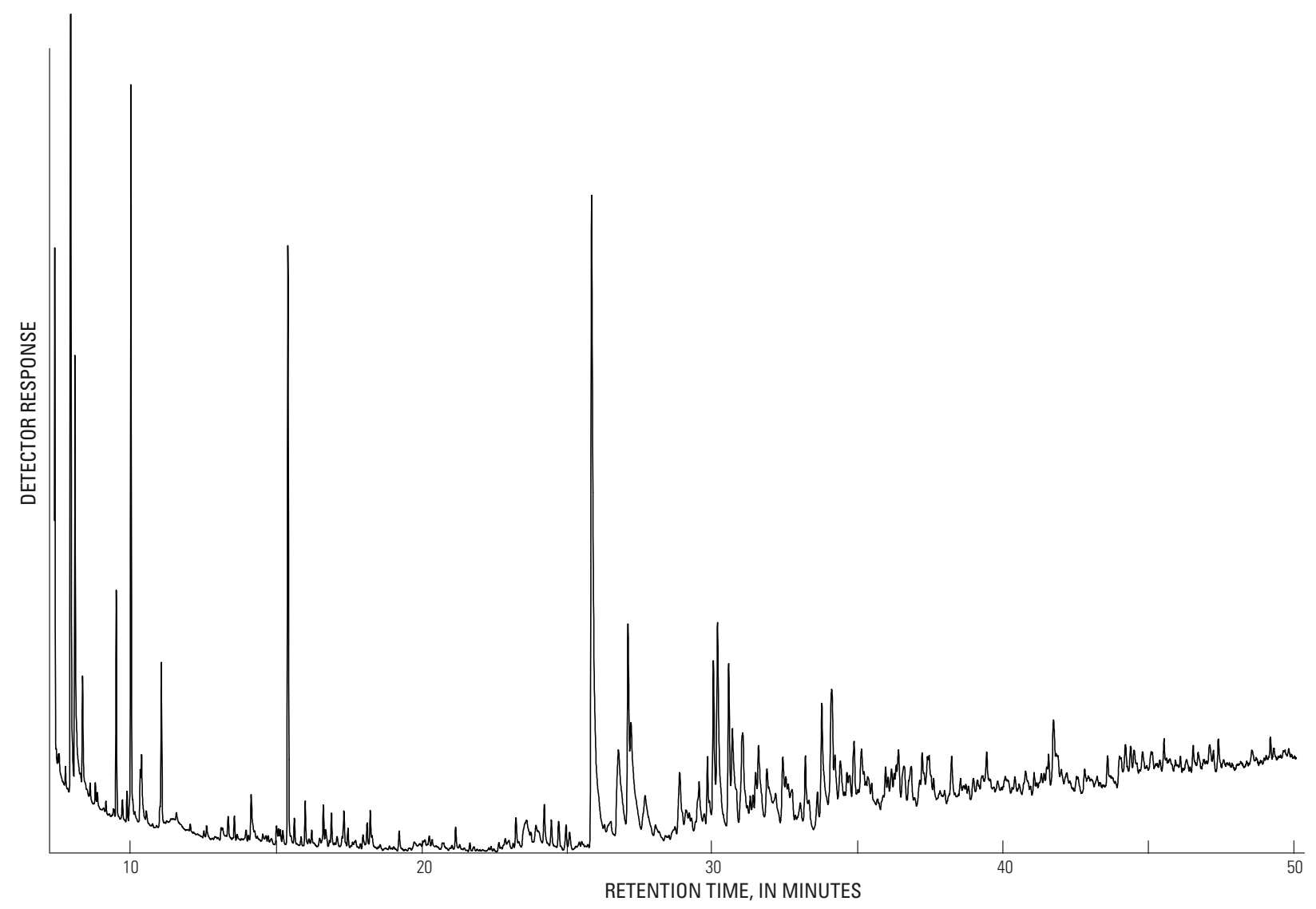

C

Figure 10 (facing page and this page). Gas chromatograms for sample 980H06A from the No. 2 French well, Trumbull County, Ohio. American Petroleum Institute (API) gravity is $43.0^{\circ}$. $A$, Whole-oil gas chromatogram, where $n$ - $C_{x}$ indicates a normal alkane with $x$ number of carbons. $B$, Saturated hydrocarbon fraction gas chromatogram. $C$, Aromatic hydrocarbon fraction gas chromatogram. Abbreviations are as follows: pr, pristane; ph, phytane. 


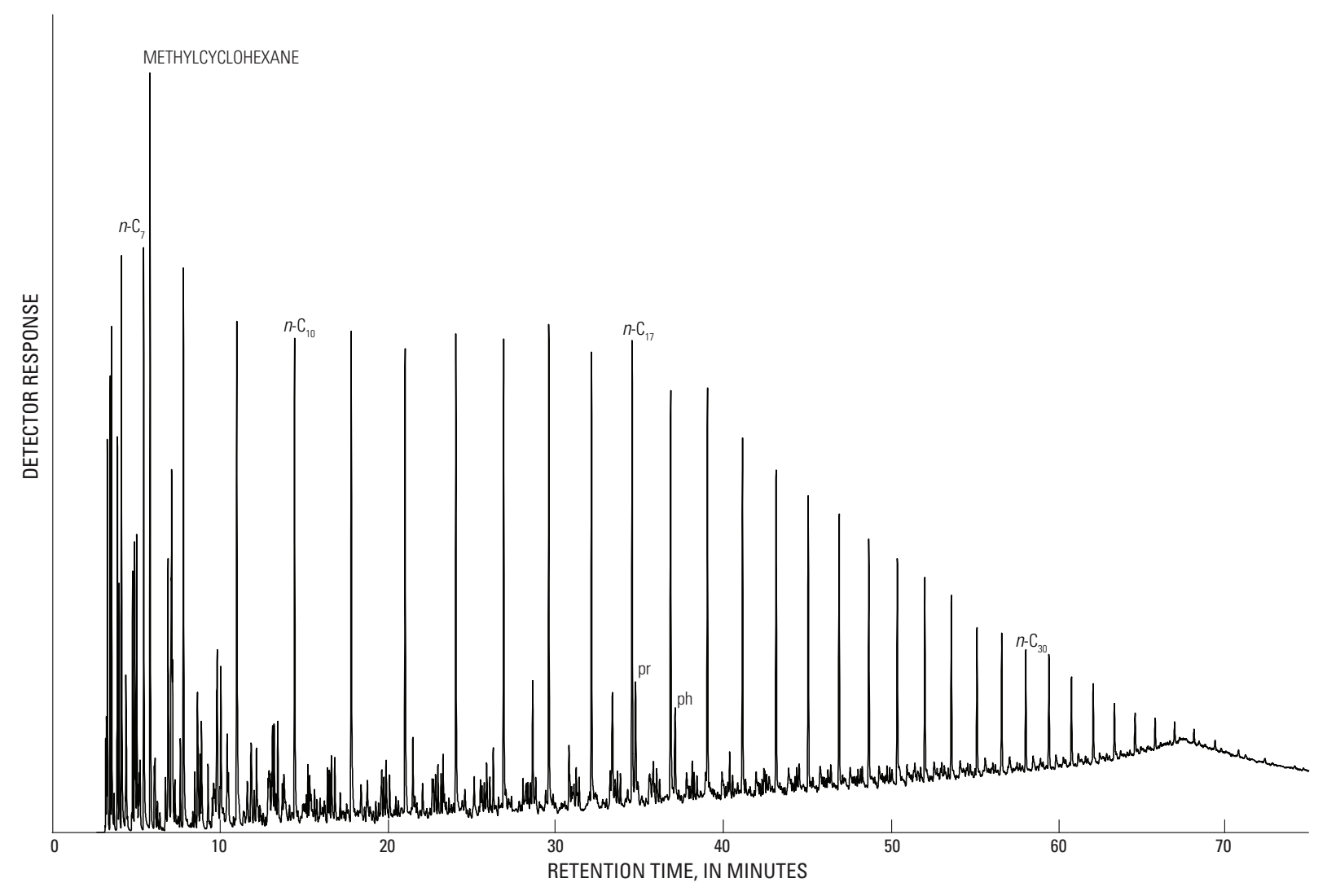

A

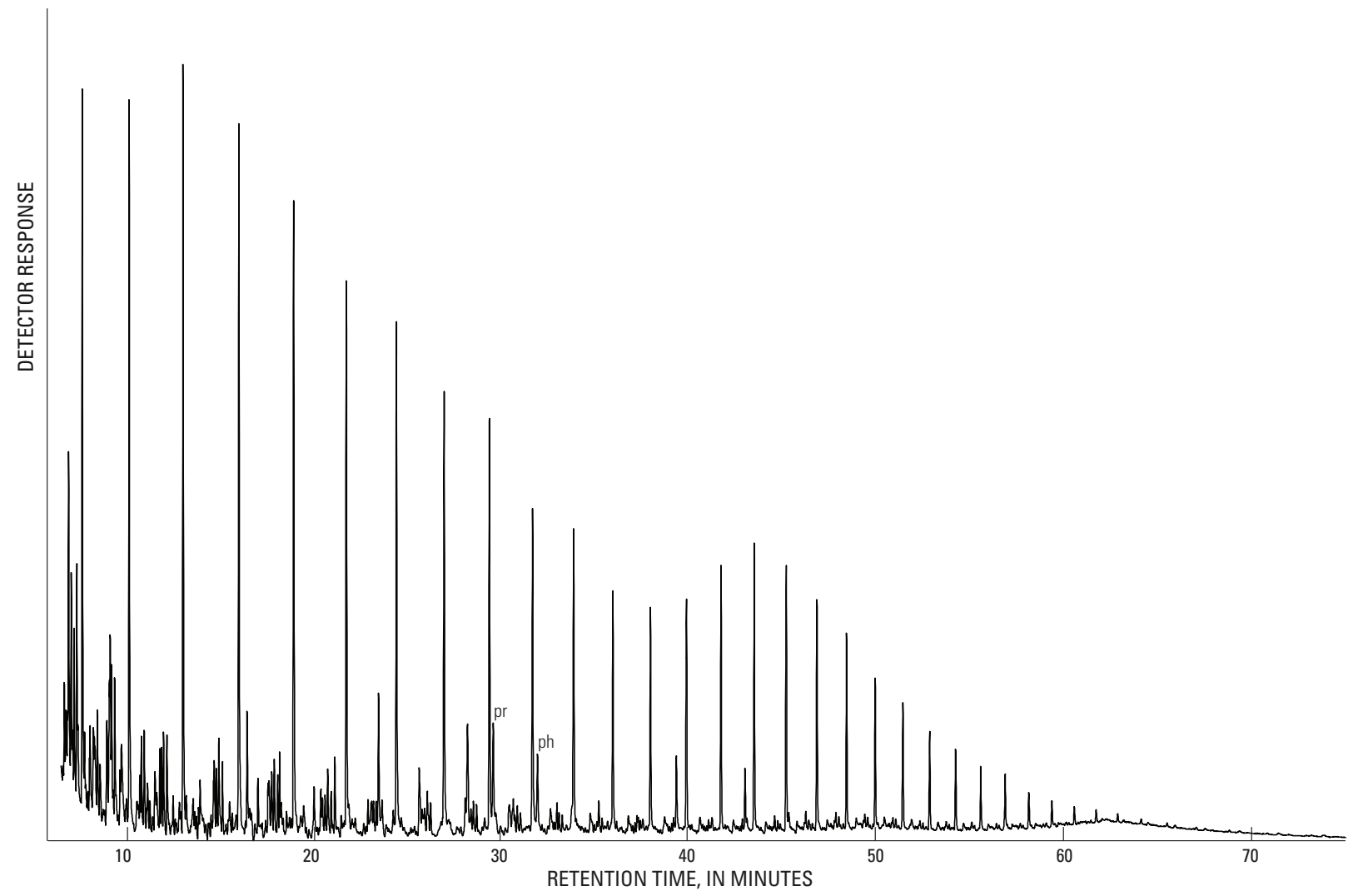




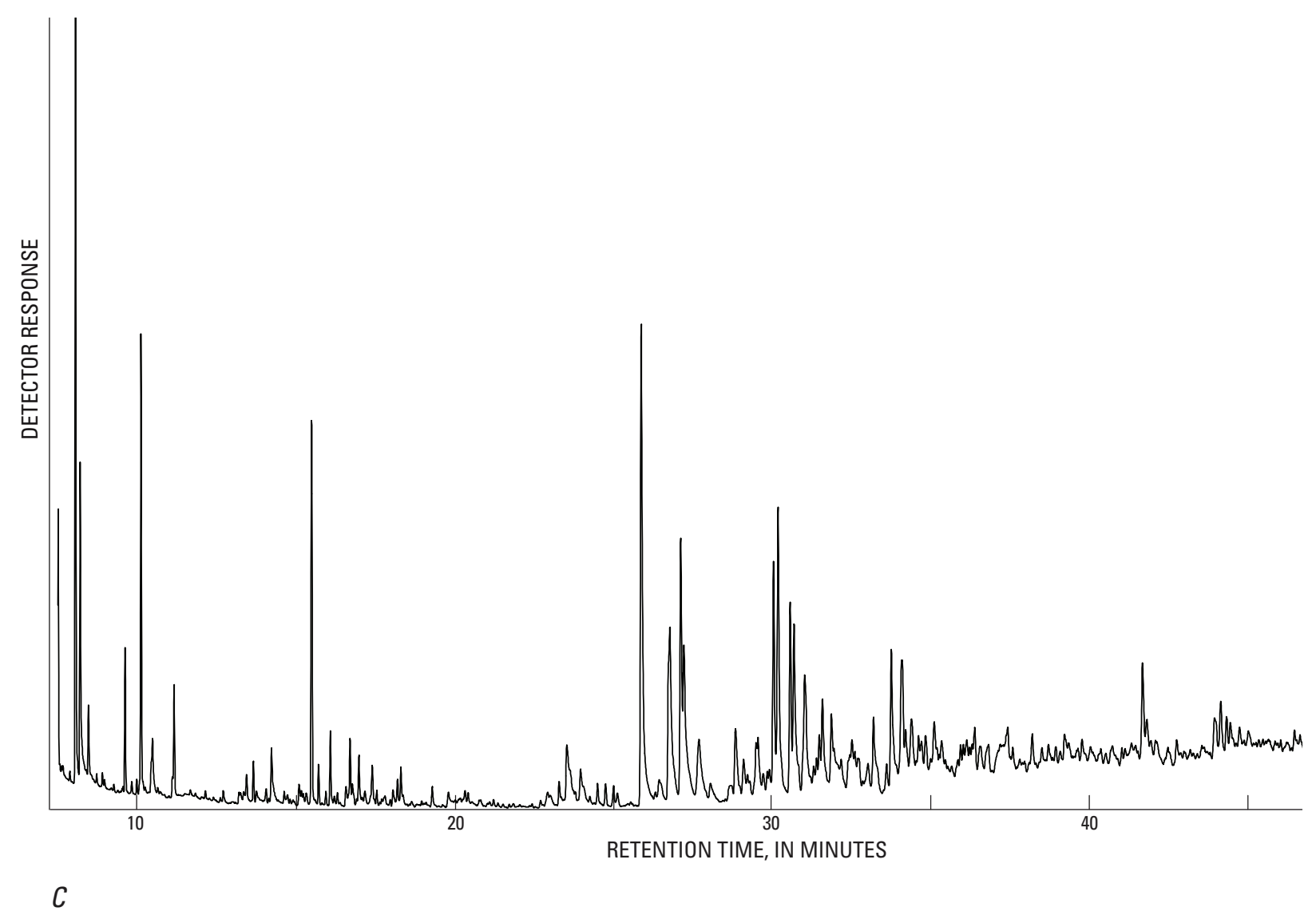

Figure 11 (facing page and this page). Gas chromatograms for sample 980H07A from the No. 3 Griffin well, Trumbull County, Ohio. American Petroleum Institute (API) gravity is $33.8^{\circ}$. $A$, Whole-oil gas chromatogram, where $n$ - $C_{x}$ indicates a normal alkane with $x$ number of carbons. $B$, Saturated hydrocarbon fraction gas chromatogram. $C$, Aromatic hydrocarbon fraction gas chromatogram. Abbreviations are as follows: pr, pristane; ph, phytane. 


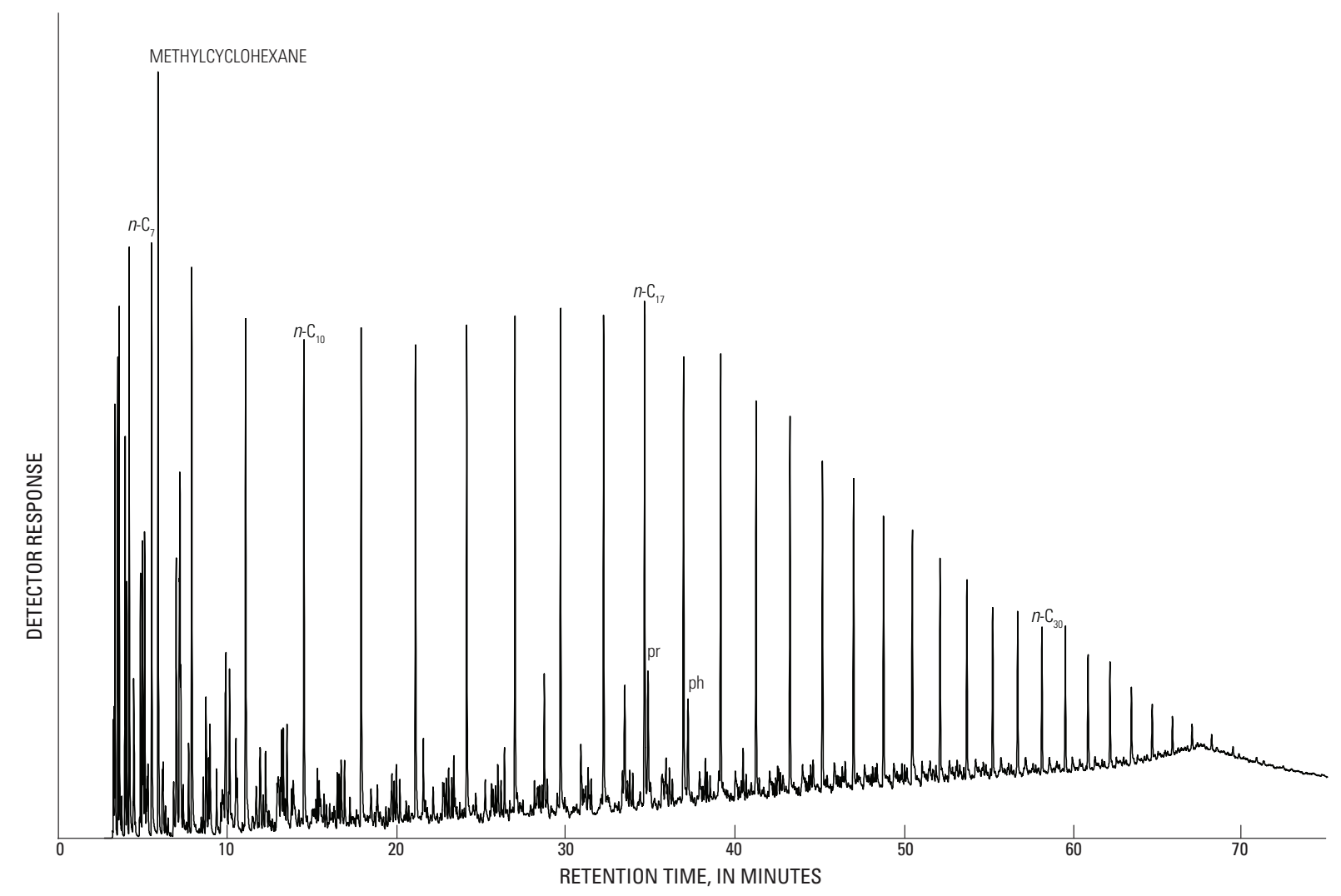

A

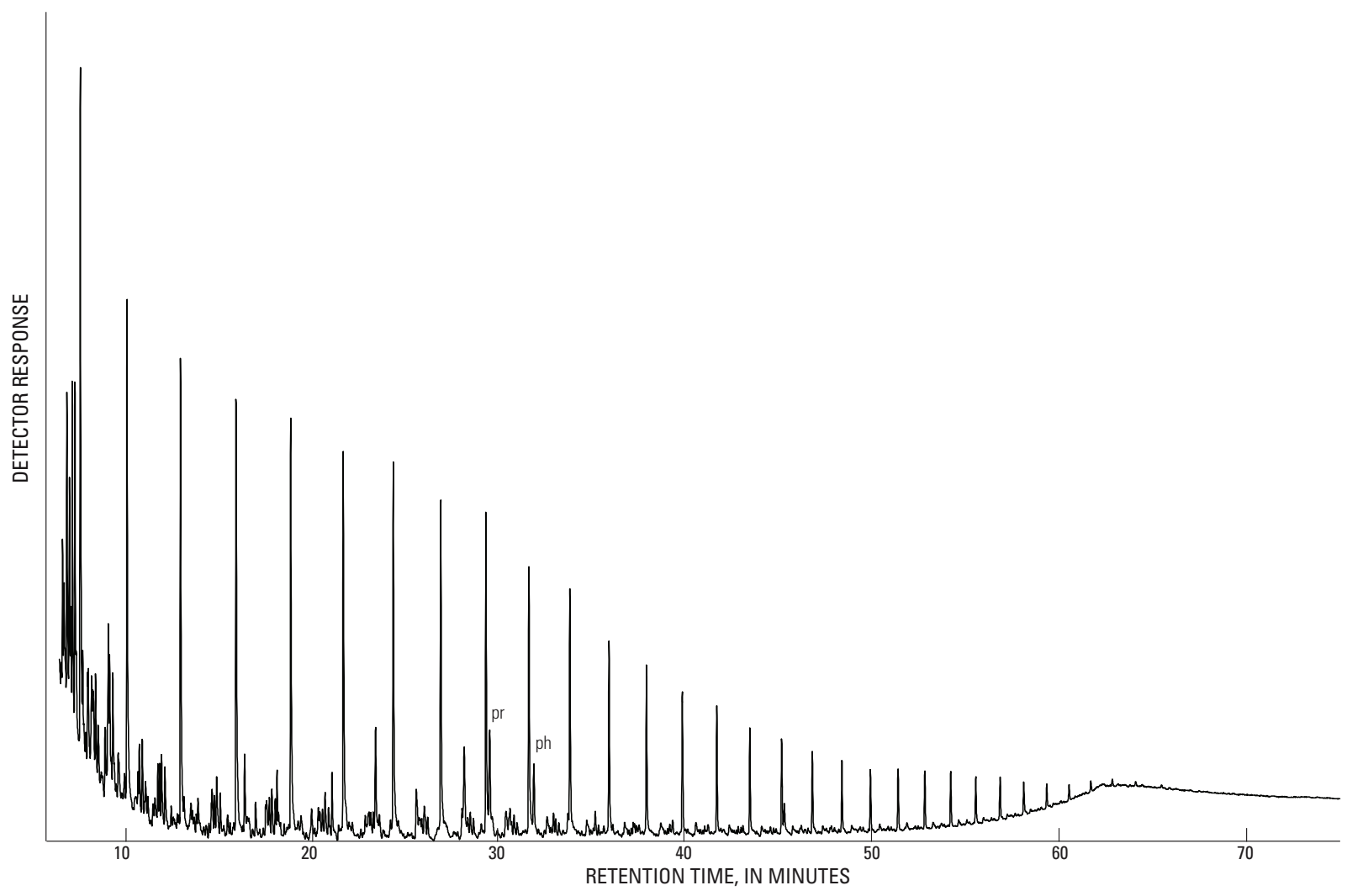




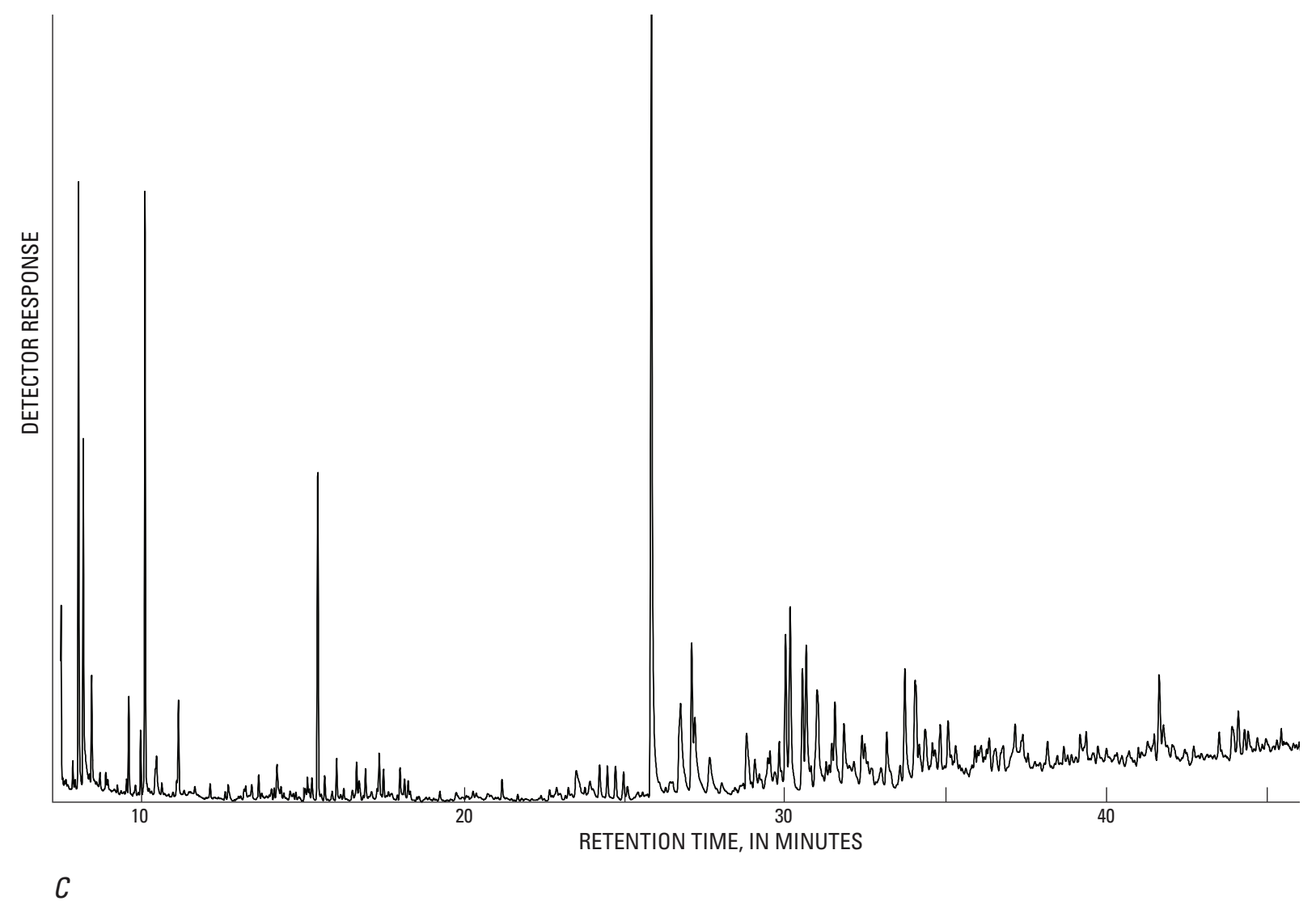

Figure 12 (facing page and this page). Gas chromatograms for sample $980 \mathrm{H} 08$ from the No. 1 Bates well, Trumbull County, Ohio. American Petroleum Institute (API) gravity is $42.9^{\circ}$. $A$, Whole-oil gas chromatogram, where $n$ - $C_{x}$ indicates a normal alkane with $x$ number of carbons. $B$, Saturated hydrocarbon fraction gas chromatogram. $C_{t}$ Aromatic hydrocarbon fraction gas chromatogram. Abbreviations are as follows: pr, pristane; ph, phytane. 


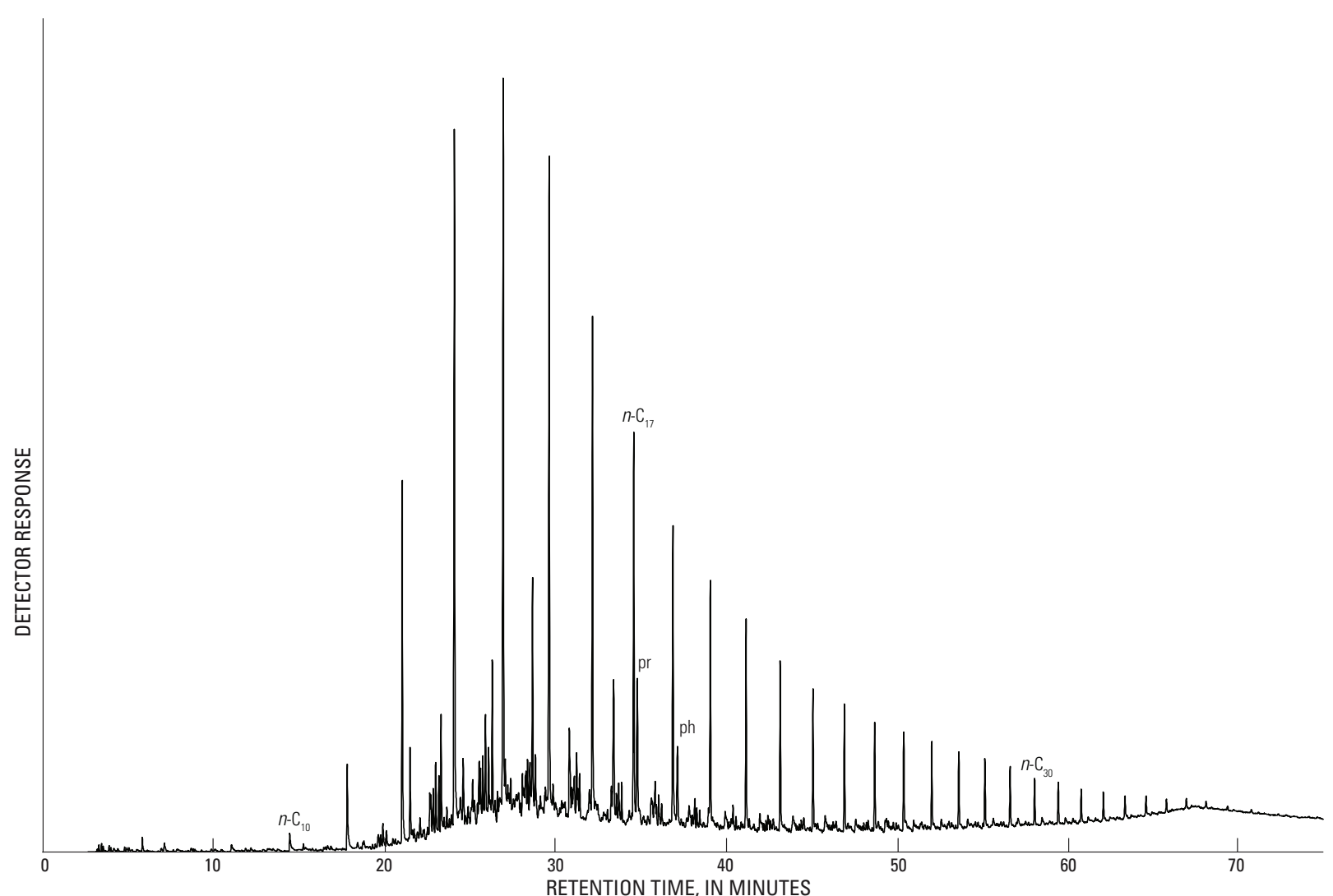

A

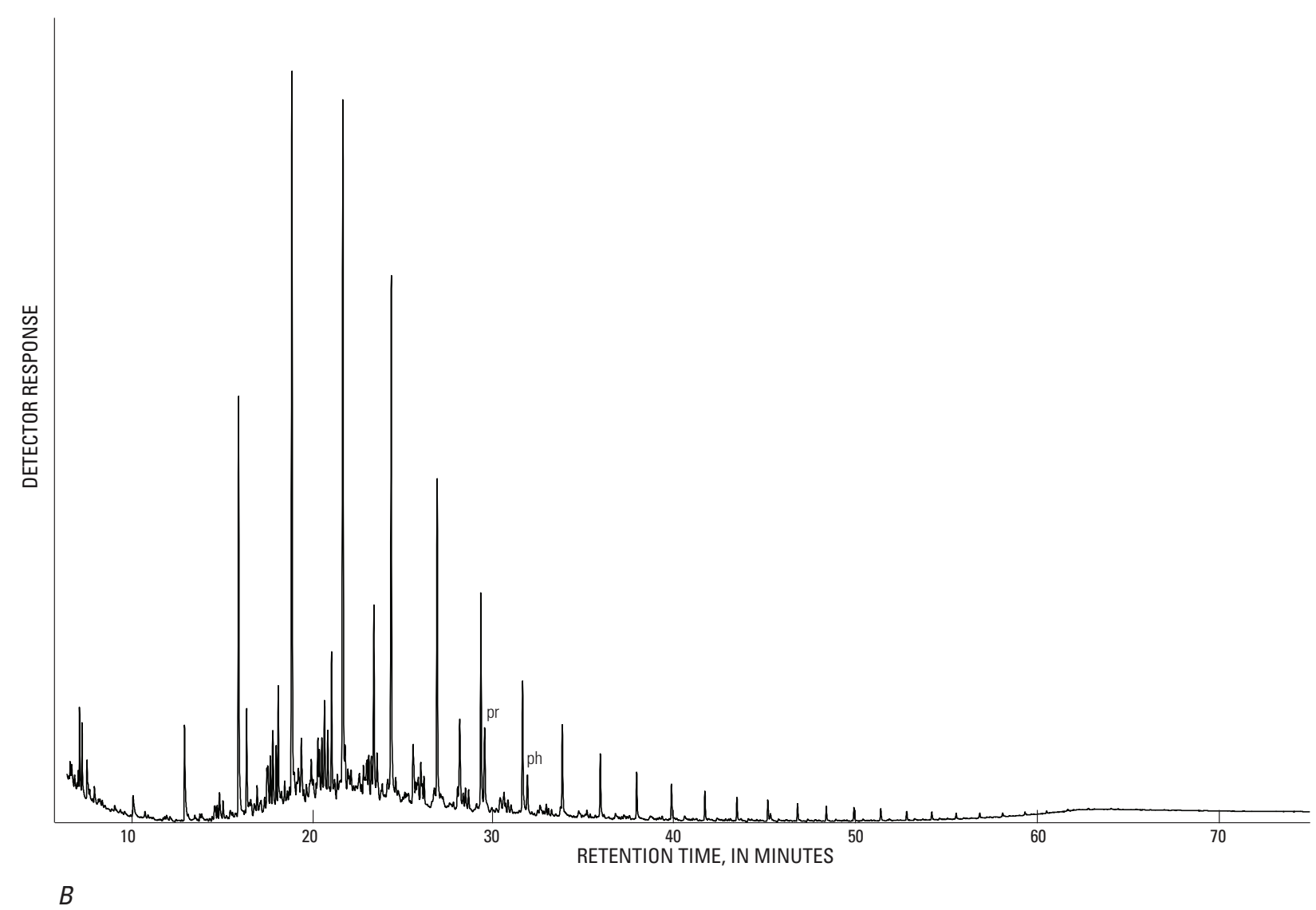




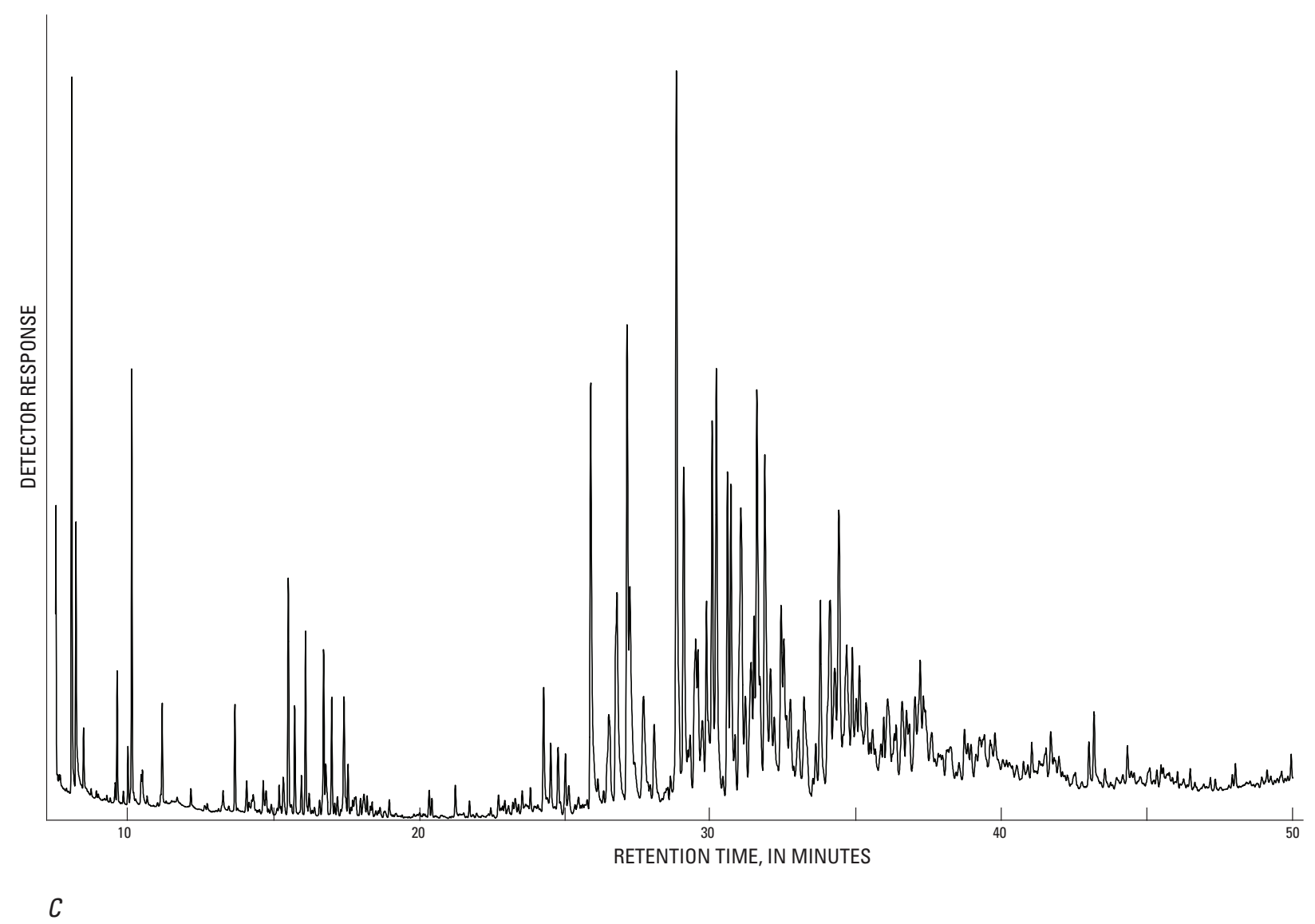

Figure 13 (facing page and this page). Gas chromatograms for sample 98PA02 from the No. 6 Weber well, Mercer County, $\mathrm{Pa}$. American Petroleum Institute (API) gravity is $39.9^{\circ}$. $A$, Whole-oil gas chromatogram, where $n$ - $\mathrm{C}_{x}$ indicates a normal alkane with $x$ number of carbons. $B$, Saturated hydrocarbon fraction gas chromatogram. $C$, Aromatic hydrocarbon fraction gas chromatogram. Abbreviations are as follows: pr, pristane; ph, phytane. 
28 Coal and Petroleum Resources in the Appalachian Basin
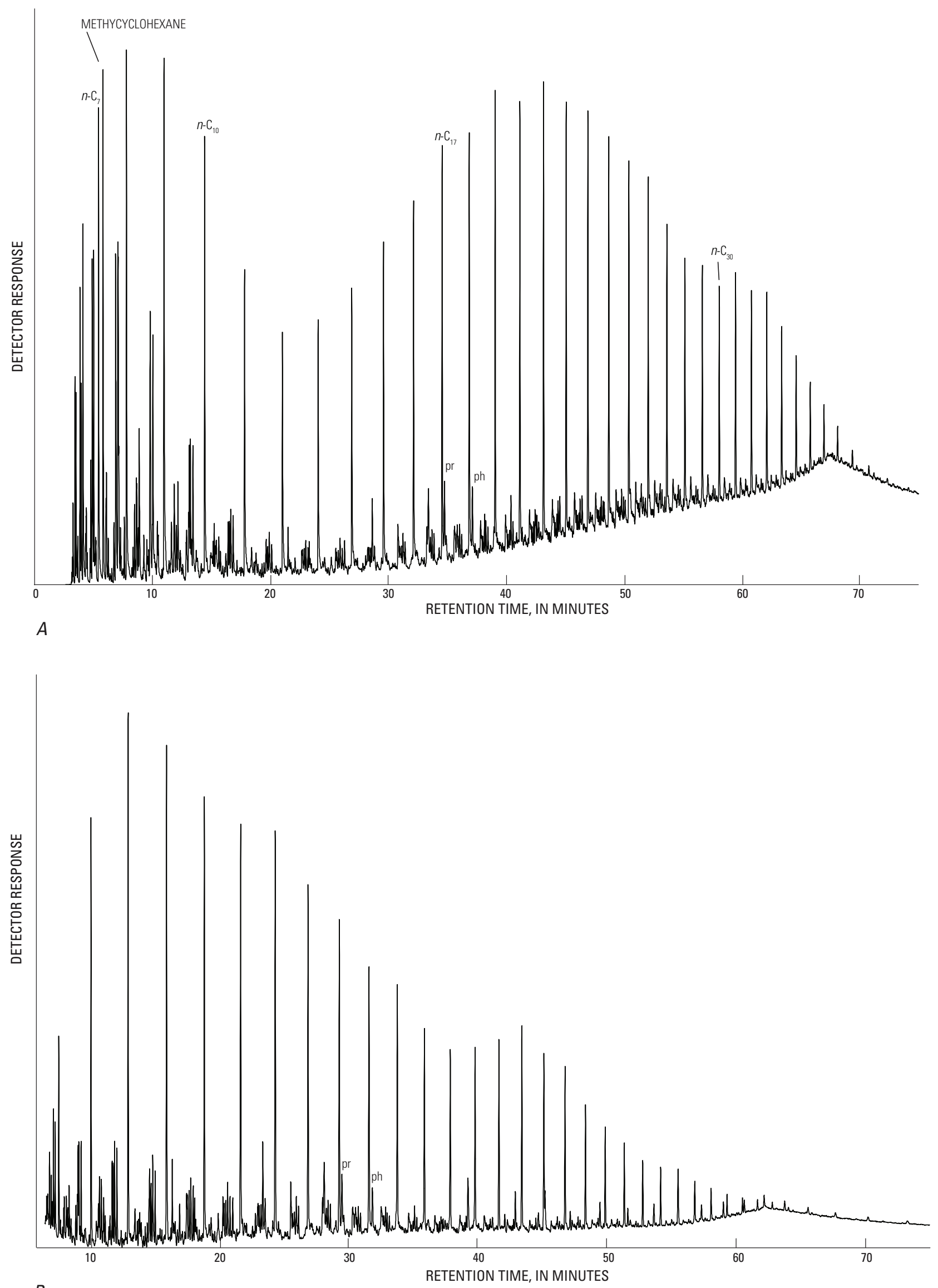


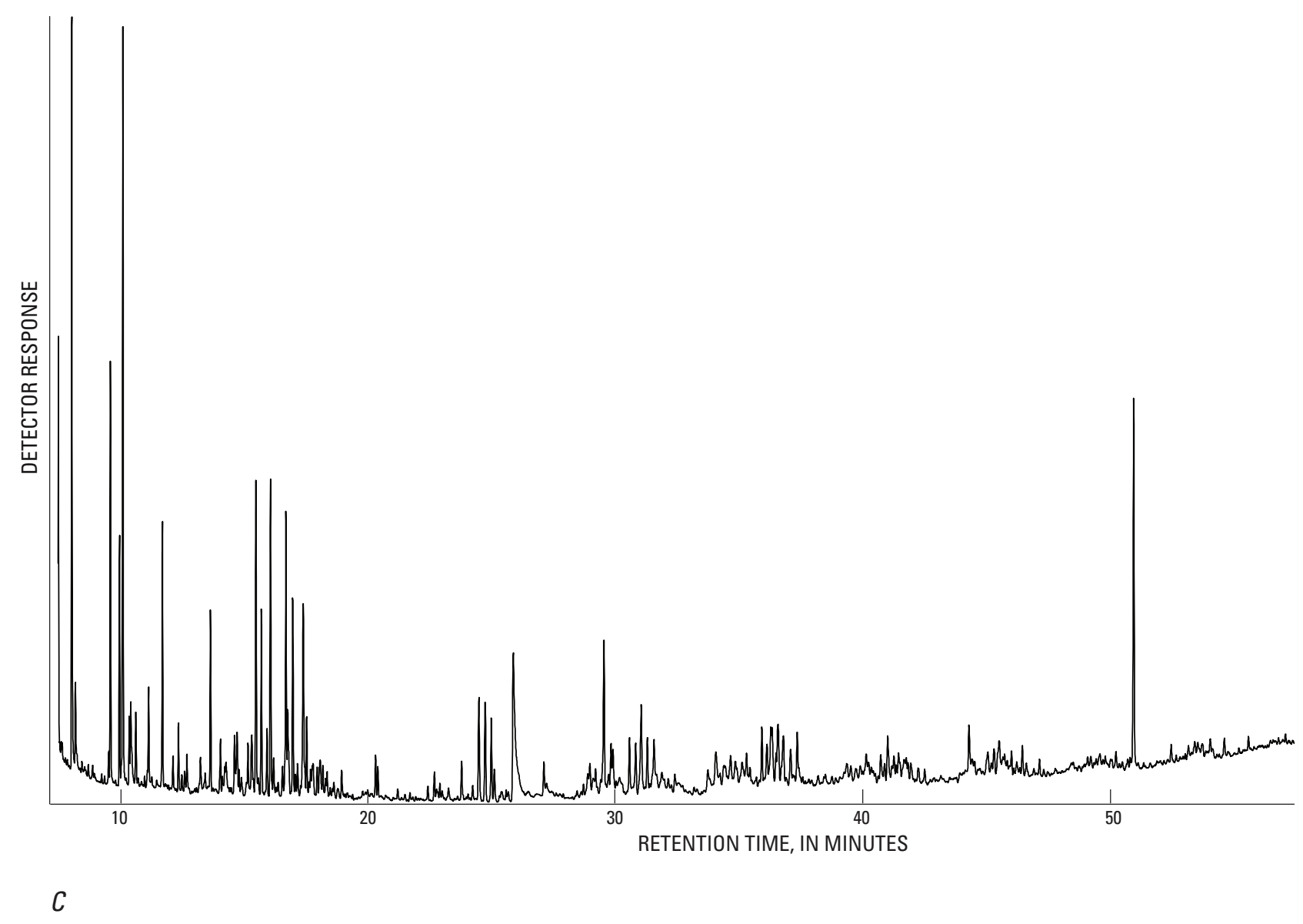

Figure 14 (facing page and this page). Gas chromatograms for sample 98PA05A from the No. 8 Oris well, Mercer County, $\mathrm{Pa}$. American Petroleum Institute (API) gravity is $45.5^{\circ}$. $A$, Whole-oil gas chromatogram, where $n-C_{x}$ indicates a normal alkane with $x$ number of carbons. $B$, Saturated hydrocarbon fraction gas chromatogram. $C$, Aromatic hydrocarbon fraction gas chromatogram. Abbreviations are as follows: pr, pristane; ph, phytane. 


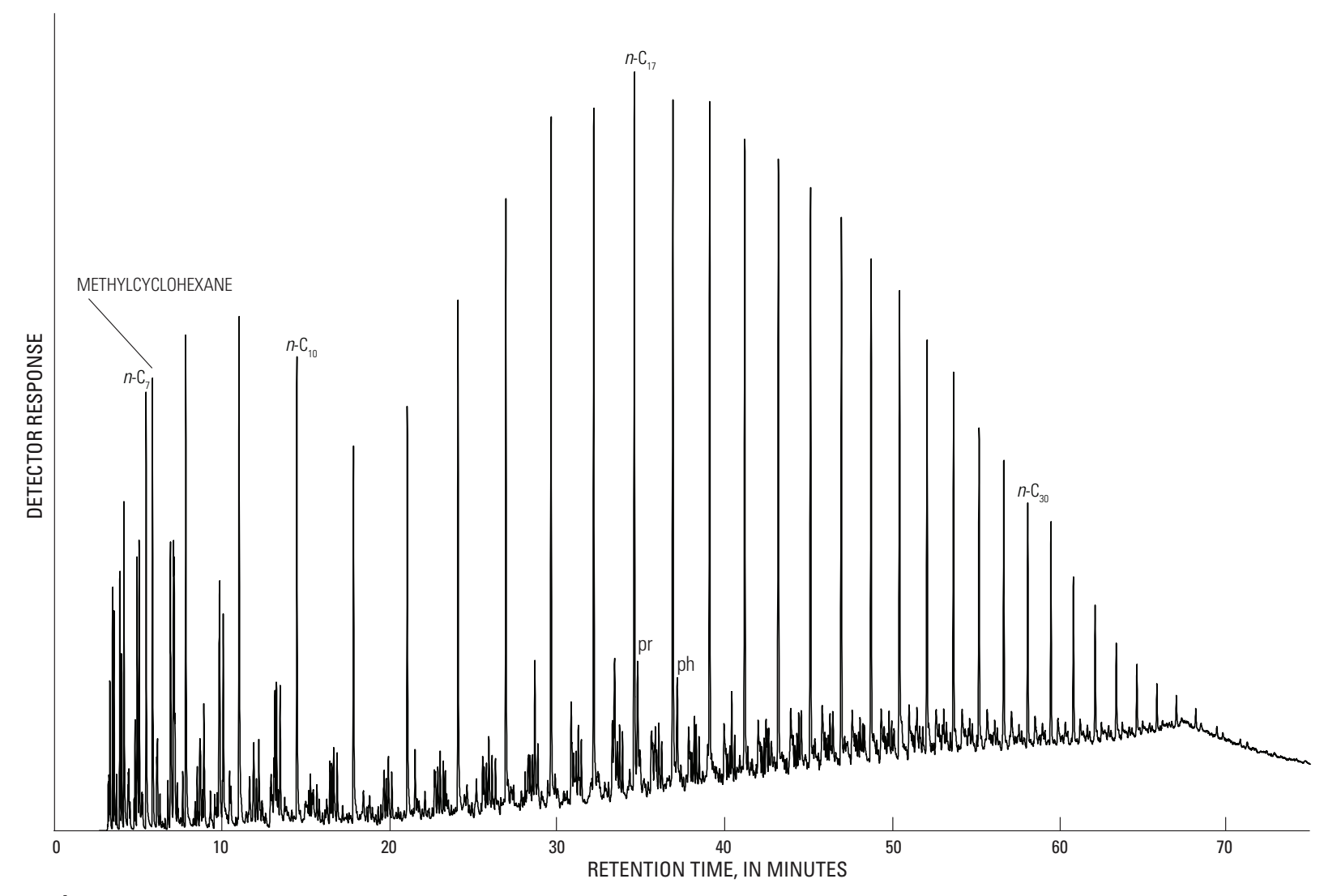

$A$

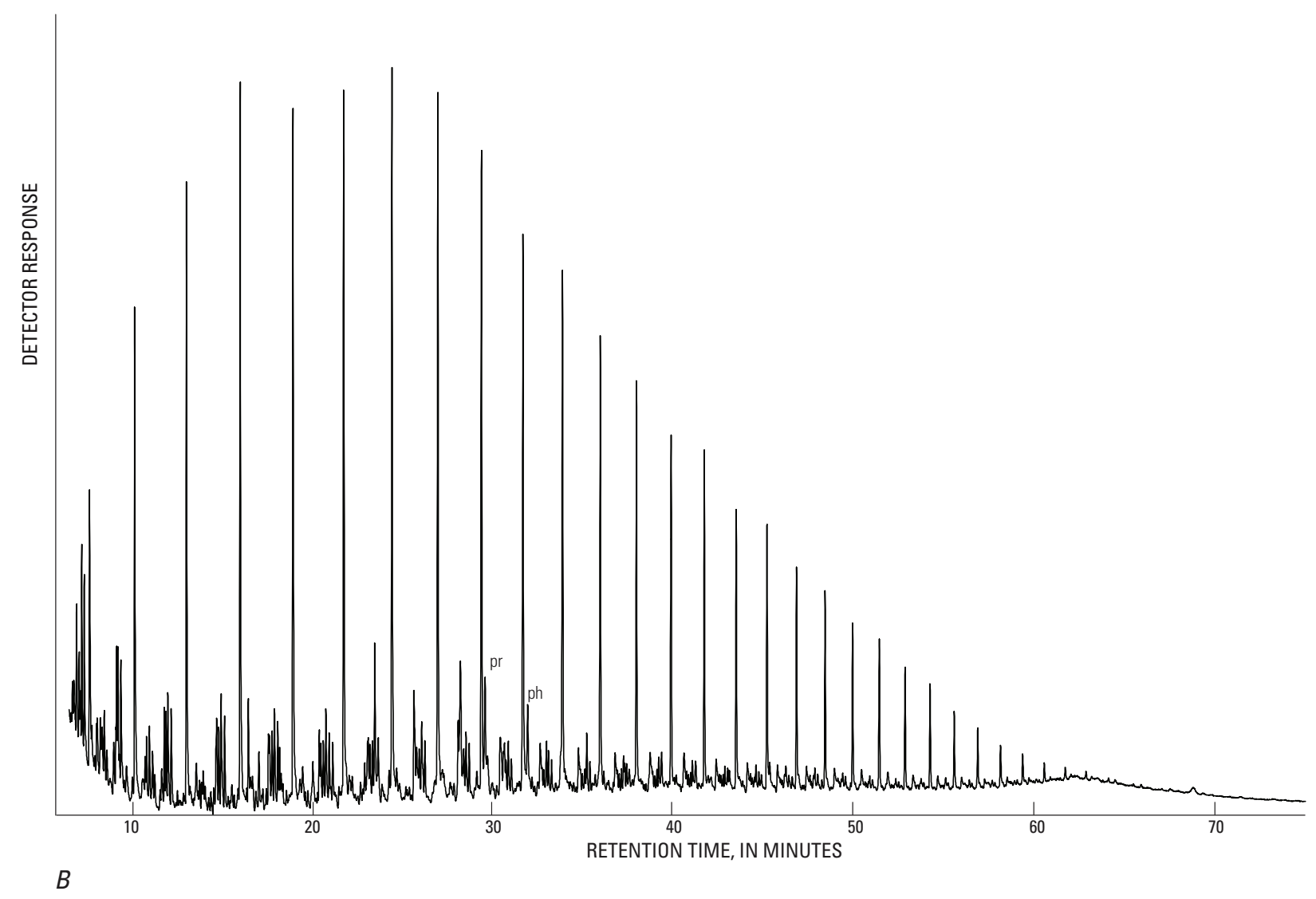




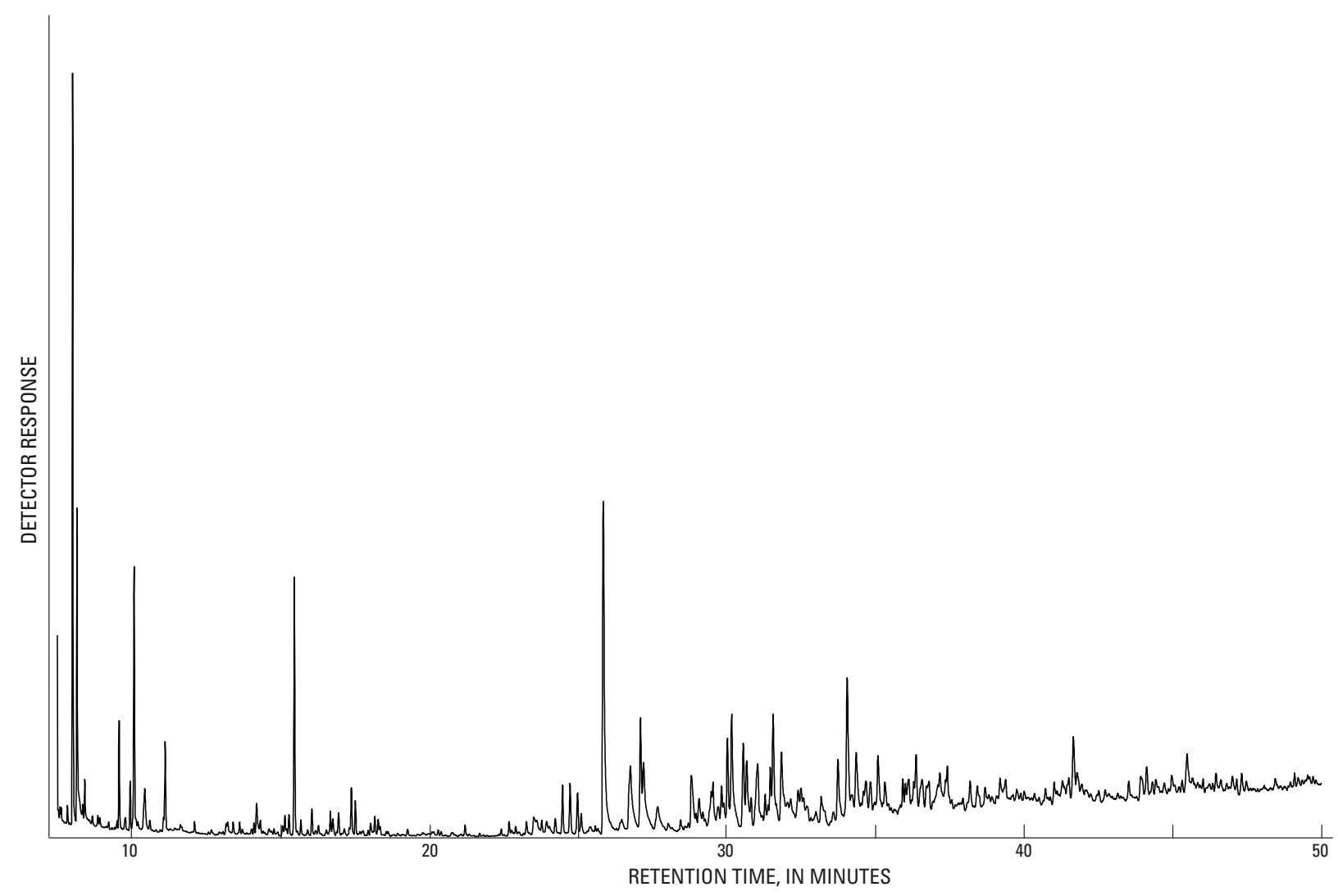

Figure 15 (facing page and this page). Gas chromatograms for sample 98PA06A from the No. 2 Gibson well, Mercer County, $\mathrm{Pa}$. American Petroleum Institute (API) gravity is $38.8^{\circ}$. $A$, Whole-oil gas chromatogram, where $n$ - $C_{x}$ indicates a normal alkane with $x$ number of carbons. $B$, Saturated hydrocarbon fraction gas chromatogram. $C$, Aromatic hydrocarbon fraction gas chromatogram. Abbreviations are as follows: pr, pristane; ph, phytane. 
Crude oil samples from the "Clinton" sandstone and Medina Group reservoirs in this study and in Burruss and Ryder (this volume, chap. G.7) are characterized by $\mathrm{pr} / n-\mathrm{C}_{17}$ and $\mathrm{ph} / n-\mathrm{C}_{18}$ values that vary broadly with their depth of production. The major exceptions are (1) sample 14 from the No. 6 Weber well, which is grouped with oils produced from much shallower depths, and (2) sample 6 from the No. 3 Griffin well, which is grouped with oils produced from much greater depths. Moreover, the carbon isotopic compositions of the saturated and aromatic fractions of the oils generally become heavier with depth. Basin-center and hybrid-conventional parts of the regional accumulation can be largely differentiated on the basis of the trends shown in figures 16 and 17.

Mass fragmentograms derived from gas chromatographymass spectrometry (GCMS) studies of the crude oil samples indicated the presence of biomarkers, although many were barely visible because of their low signal-to-noise ratios. Surprisingly, the best fragmentograms were from the depleted oil in the No. 6 Weber well; terpane (mass-to-charge ratio $(\mathrm{m} / \mathrm{z})=191$ and sterane $\mathrm{m} / \mathrm{z}=217)$ fragmentograms of this oil are shown in figures $18 \mathrm{~A}$ and $18 \mathrm{~B}$, respectively.

\section{Conclusions}

\section{Natural Gases}

The striking distribution of $\delta^{13} \mathrm{C}$ methane versus $\delta^{2} \mathrm{H}$ methane compositions is clearly a function of the thermal maturity of the gases (fig. 4). In addition, given the orderly increase toward heavier isotopes with depth, there appears to have been very little mixing of the gases in the "Clinton" sandstone and Medina Group sandstone reservoirs after entrapment. Also, these data imply a common source rock for the gases. Several explanations are possible for the isotopic distributions shown in figure 4. In the first model, these gases may have been introduced into Lower Silurian reservoirs from a distant source, become trapped, and then thermally modified in situ as the reservoirs gradually achieved maximum burial. In the second model, gases may have been introduced from a local source rock and then were trapped before they were allowed to migrate laterally. In these two models, the gases had minimal mobility during late-stage basin uplift. In a third model, the isotopic character of the gases is a late-stage, leakage and fractionation phenomenon whereby the volume of the escaped gas is directly related to the thickness of overburden; therefore, isotopic compositions would be heaviest in gases having the greatest overburden thicknesses (Laughrey and Baldassare, 1998).

Furthermore, conodont alteration index (CAI) isograds for Middle Ordovician carbonate rocks in the Appalachian basin (Repetski and others, 2002; this volume, chap. F.1) show a consistently lower thermal maturity value, for a given locality, than that of the gases (Jenden and others, 1993) (fig. 4). Figure 4 suggests that gases in the "Clinton" sandstone and Medina Group sandstones were derived from source rocks that have thermal maturity values that are about 1 to 1.5 percent greater (in terms of vitrinite reflectance equivalence (VRE) (Nöth, 1991)) than the thermal maturity values of the underlying Middle Ordovician strata based on CAI isograds. A similar discrepancy occurs when the thermal maturity of the gases is compared with the thermal maturity of the overlying Lower to Middle Devonian strata based on CAI isograds and vitrinite reflectance $\left(\% \mathrm{R}_{\mathrm{o}}\right)$ isoreflectance lines.

The fact that these gases have a significantly higher thermal maturity than either the underlying Ordovician or overlying Devonian strata suggests that they migrated from deeper within the basin. Moreover, a Middle to Upper Ordovician source rock (Utica Shale) is favored over a Devonian shale source rock because of the shorter migration distance of 25 to $50 \mathrm{mi}$ for the Utica Shale compared to the more than $100 \mathrm{mi}$ required by Devonian strata to account for the observed thermal maturity of the gases. Although these data are most consistent with the first model for the origin of the gases, the third model cannot be rejected. In several natural gas samples in this study, methane $\delta^{13} \mathrm{C}$ values are greater than ethane $\delta^{13} \mathrm{C}$ values (table 2 ), which may have resulted from the mixing of mature and post-mature gases (Jenden and others, 1993; Laughrey and Baldassare, 1998); however, diffusive leakage of gas through the overburden rock (as permitted in the third model) may be an alternate explanation (Laughrey and Baldassare, 1998).

\section{Crude Oils}

For the oil samples, the majority of the $n$-alkane distributions in the whole-oil gas chromatograms (figs. $6 A-13 A$, $15 \mathrm{~A}$ ) show the following: (1) a broad spectrum of $n$-alkanes ranging from $n-\mathrm{C}_{10}$ through $n-\mathrm{C}_{35}$, (2) modest odd-carbonnumber preference in the $n-\mathrm{C}_{15}$ through $n$ - $\mathrm{C}_{19}$ range, and (3) the presence of the isoprenoids pristane and phytane. The major exception to the rule is the oil sample from the No. 6 Weber well (fig. 13A), which has an incomplete spectrum of $n$-alkanes ( $n$ - $\mathrm{C}_{10}$ and $n$ - $\mathrm{C}_{11}$ are nearly depleted) and also lacks the odd-carbon-number predominance in the $n$ - $\mathrm{C}_{15}$ through $n$ - $\mathrm{C}_{19}$ range. As noted earlier, the characteristics of the No. 6 Weber oil sample probably were caused by evaporative loss during sampling and storage.

The oil samples analyzed in this investigation have the same basic composition as other oil samples taken from the "Clinton" sandstone reservoir in Ohio (Cole and others, 1987; Burruss and Ryder, this volume, chap. G.7) and oils from Cambrian to Ordovician reservoirs in Ohio (Cole and others, 1987; Ryder and others, 1998). These basic similarities suggest a common source rock, probably the Middle to Upper Ordovician Utica Shale, for both the "Clinton" sandstone and the Cambrian to Ordovician reservoirs (Cole and others, 1987; Ryder and others, 1998). There is not enough geochemical and geological evidence, however, to unambiguously distinguish a possible Lower to Middle Devonian black shale source rock from the probable source in Silurian shale and carbonate units (Ryder and Zagorski, 2003). 


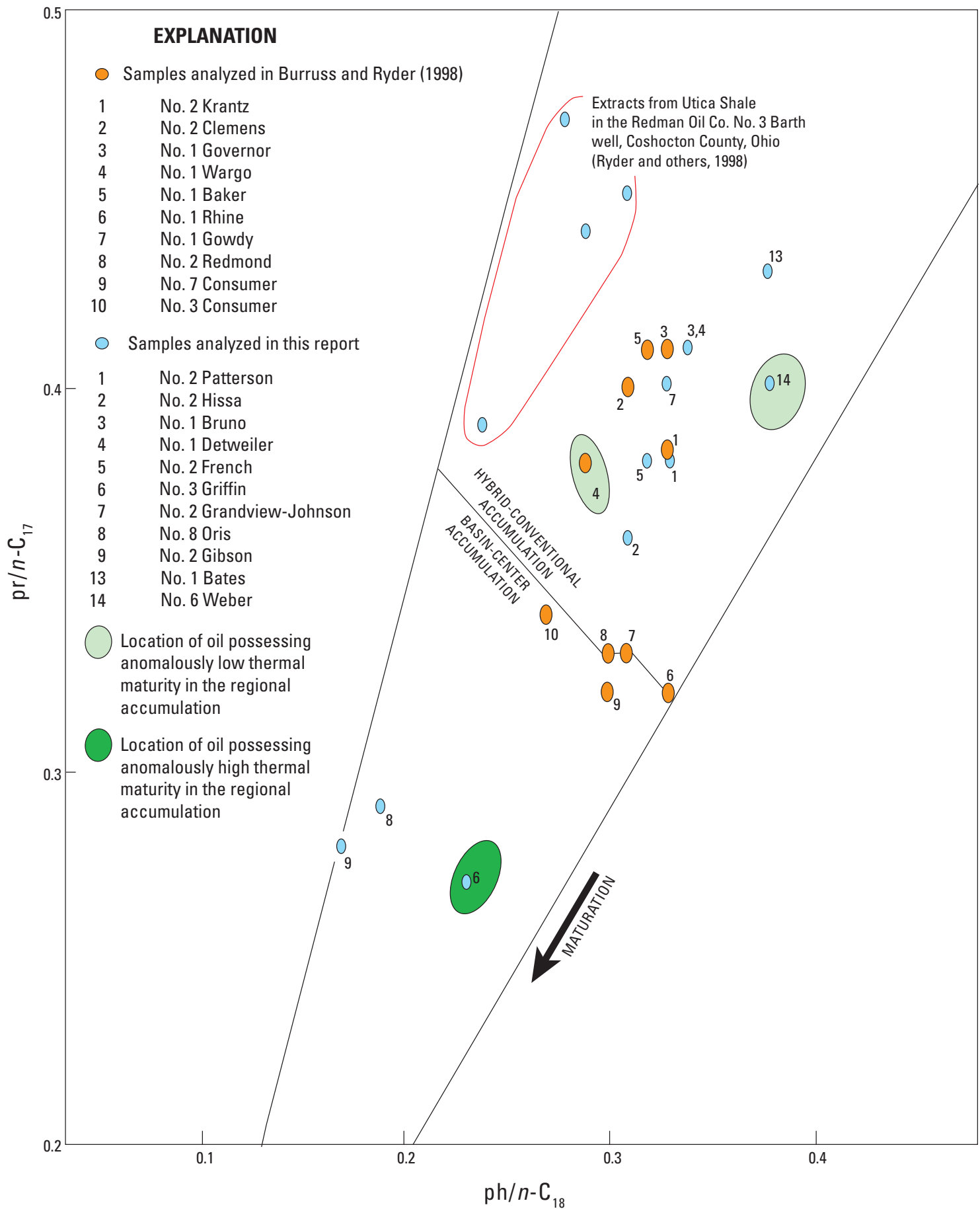

Figure 16. Graph showing $\mathrm{ph} / n-\mathrm{C}_{18}$ plotted against $\mathrm{pr} / n-\mathrm{C}_{17}$ for "Clinton" sandstone and Medina Group oil samples and Utica Shale bitumen extracts. Abbreviations are as follows: ph, phytane; pr; pristane; $n-\mathrm{C}_{177^{\prime}}$ hetadecane; $n-C_{18}$ octadecane. 


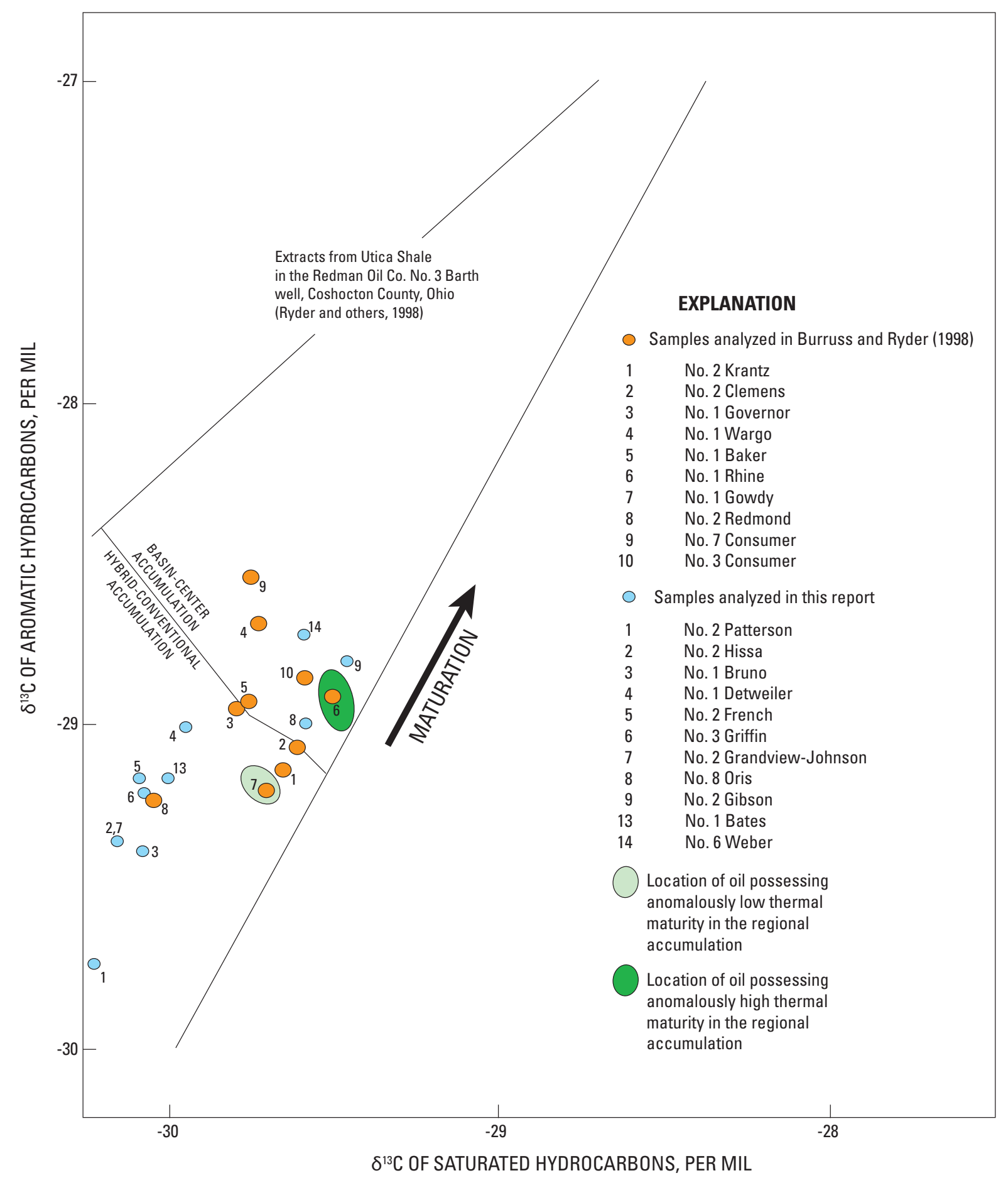

Figure 17. Graph showing the isotopic composition of carbon $\left(\delta^{13} \mathrm{C}\right)$ in the saturated hydrocarbon fraction plotted against $\delta^{13} \mathrm{C}$ in the aromatic hydrocarbon fraction for oil samples from the "Clinton" sandstone and Medina Group, and bitumen extracts from the Utica Shale.

Figure 18 (facing page). Mass fragmentograms for sample 98PA02 from the No. 6 Weber well, Mercer $\mathrm{C} 0 ., \mathrm{Pa} . A$, Terpane mass fragmentogram, mass-to-charge ratio $(\mathrm{m} / \mathrm{z})$ of 191.180 . $B$, Sterane mass fragmentogram, $\mathrm{m} / \mathrm{z}$ of 217.1956 . For parts $A$ and $B$, combinations of numbers and letters on peaks are defined in table 5. 


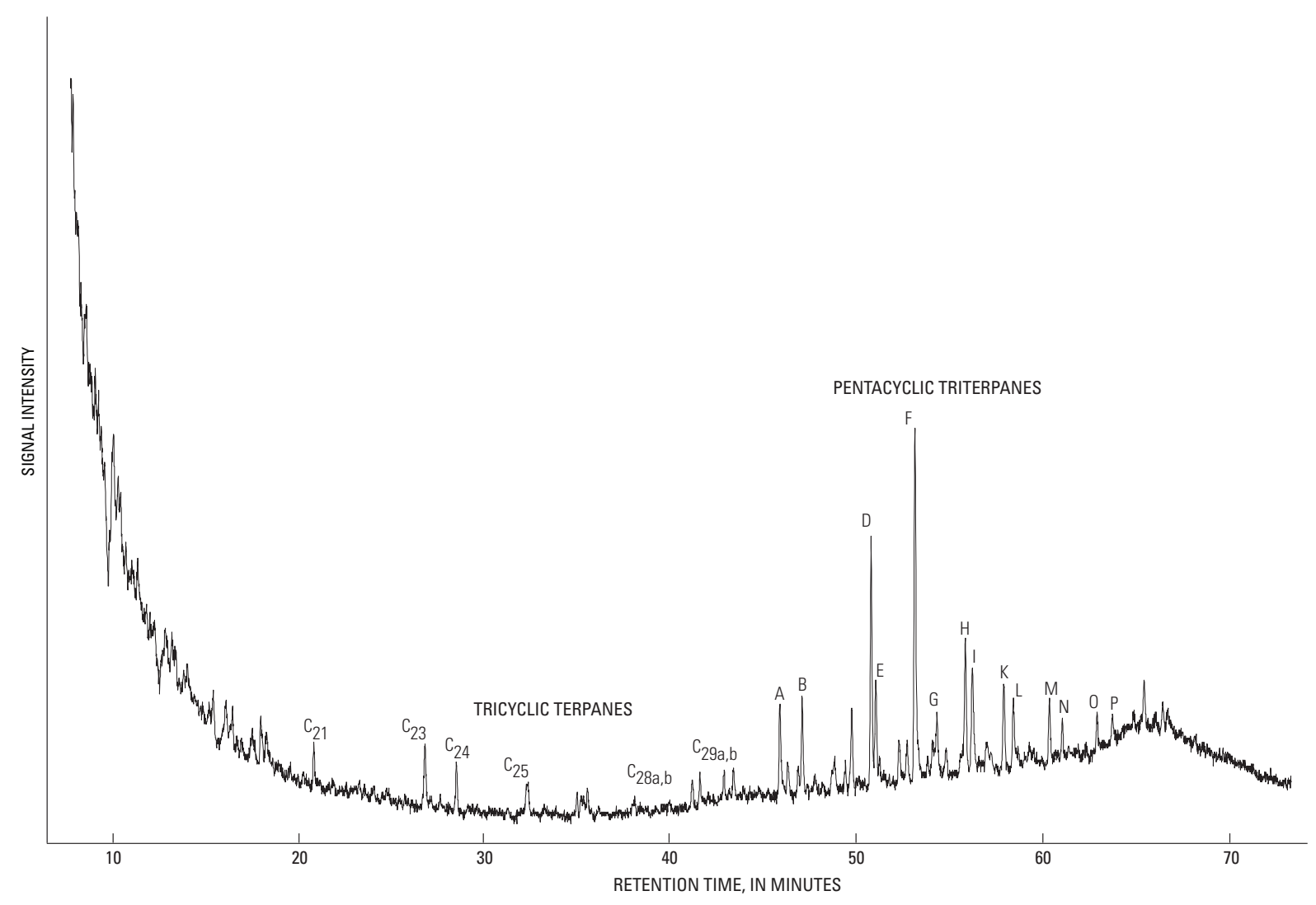

A

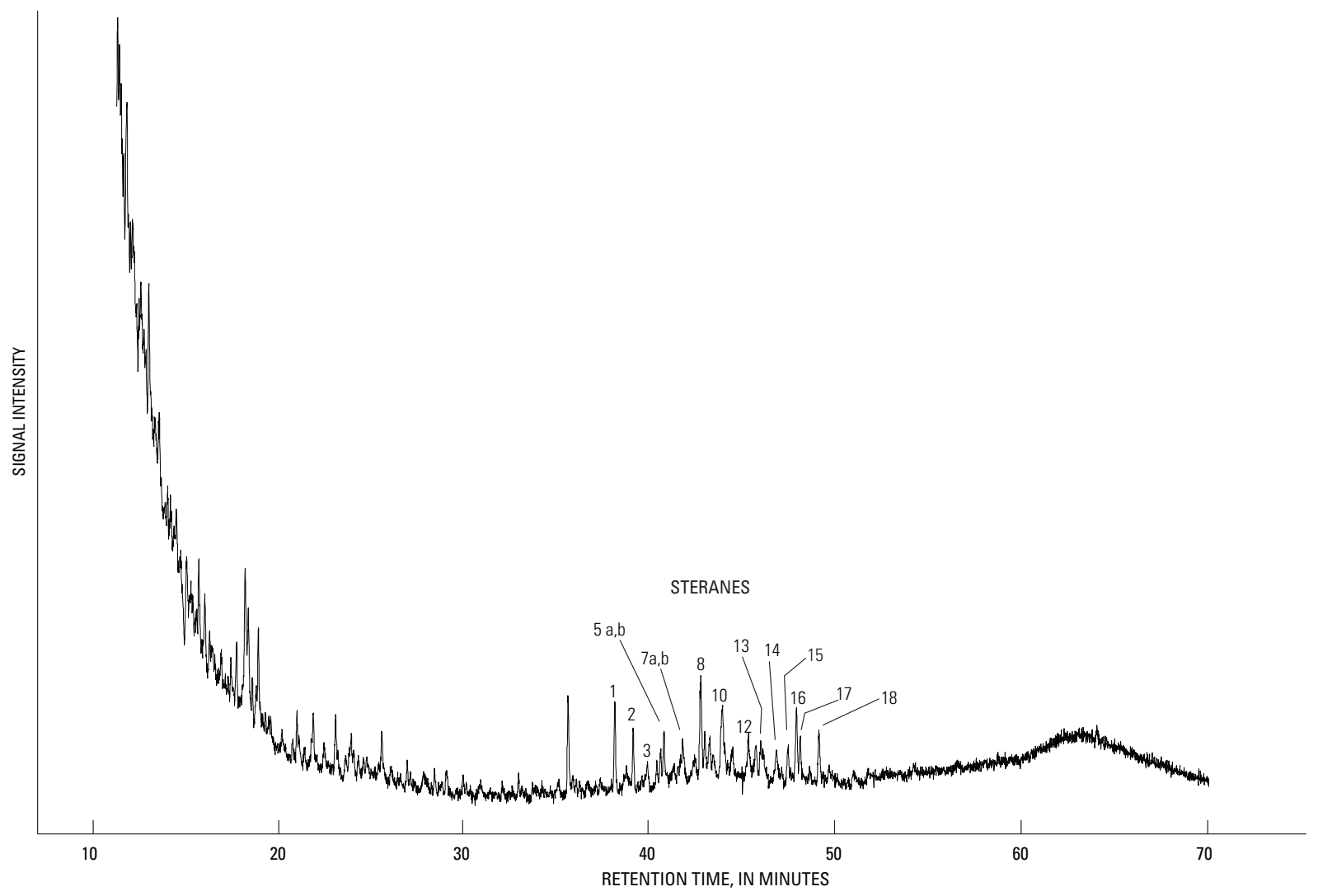


Table 5. Terpane and sterane compounds identified in the saturated fraction of the oil from the No. 6 Weber well, Mercer County, Pa.

\begin{tabular}{|c|c|c|}
\hline $\begin{array}{c}\text { Label } \\
\text { (see } \\
\text { fig. 18) }\end{array}$ & $\begin{array}{l}\text { Molecular } \\
\text { formula }\end{array}$ & Compound \\
\hline \multicolumn{3}{|r|}{ Tricyclic terpanes } \\
\hline $\mathrm{C}_{21}$ & $\mathrm{C}_{21} \mathrm{H}_{38}$ & $\mathrm{C}_{21}$ tricyclic terpane \\
\hline $\mathrm{C}_{23}$ & $\mathrm{C}_{23} \mathrm{H}_{42}$ & $\mathrm{C}_{23}$ tricyclic terpane \\
\hline $\mathrm{C}_{24}$ & $\mathrm{C}_{24} \mathrm{H}_{44}$ & $\mathrm{C}_{24}$ tricyclic terpane \\
\hline $\mathrm{C}_{25}$ & $\mathrm{C}_{25} \mathrm{H}_{46}$ & $\mathrm{C}_{25}$ tricyclic terpane \\
\hline $\mathrm{C}_{28 \mathrm{a}}$ & $\mathrm{C}_{28} \mathrm{H}_{50}$ & $\mathrm{C}_{28}[22 \mathrm{~S}]$ tricyclic terpane \\
\hline $\mathrm{C}_{28 \mathrm{~b}}$ & $\mathrm{C}_{28} \mathrm{H}_{50}$ & $\mathrm{C}_{28}[22 \mathrm{R}]$ tricyclic terpane \\
\hline $\mathrm{C}_{29 \mathrm{a}}$ & $\mathrm{C}_{29} \mathrm{H}_{52}$ & $\mathrm{C}_{29}[22 \mathrm{~S}]$ tricyclic terpane \\
\hline$\underline{\mathrm{C}_{29 \mathrm{~b}}}$ & $\mathrm{C}_{29} \mathrm{H}_{52}$ & $\mathrm{C}_{29}[22 \mathrm{R}]$ tricyclic terpane \\
\hline \multicolumn{3}{|r|}{$\begin{array}{ll}\text { Pentacyclic triterpanes } \\
\end{array}$} \\
\hline A & $\mathrm{C}_{27} \mathrm{H}_{46}$ & $18 \alpha$-trisneonorhopane $[\mathrm{Ts}]$ \\
\hline B & $\mathrm{C}_{27} \mathrm{H}_{46}$ & $17 \alpha$-trisneonorhopane $[\mathrm{Tm}]$ \\
\hline $\mathrm{D}$ & $\mathrm{C}_{29} \mathrm{H}_{50}$ & Norhopane $\left[\mathrm{C}_{29}\right]$ \\
\hline $\mathrm{E}$ & $\mathrm{C}_{29} \mathrm{H}_{50}$ & $18 \alpha$-neonorhopane $\left[\mathrm{C}_{29}\right]$ \\
\hline $\mathrm{F}$ & $\mathrm{C}_{30} \mathrm{H}_{52}$ & Hopane $\left[\mathrm{C}_{30}\right]$ \\
\hline G & $\mathrm{C}_{30} \mathrm{H}_{52}$ & $17 \beta, 21 \alpha$-moretane $\left[\mathrm{C}_{30}\right]$ \\
\hline $\mathrm{H}$ & $\mathrm{C}_{31} \mathrm{H}_{54}$ & 22S-homohopane $\left[\mathrm{C}_{31}\right]$ \\
\hline I & $\mathrm{C}_{31} \mathrm{H}_{54}$ & 22R-homohopane $\left[\mathrm{C}_{31}\right]$ \\
\hline K & $\mathrm{C}_{32} \mathrm{H}_{56}$ & 22S-bishomohopane $\left[\mathrm{C}_{32}\right]$ \\
\hline $\mathrm{L}$ & $\mathrm{C}_{32} \mathrm{H}_{56}$ & 22R-bishomohopane $\left[\mathrm{C}_{32}\right]$ \\
\hline M & $\mathrm{C}_{33} \mathrm{H}_{58}$ & 22S-trishomohopane $\left[\mathrm{C}_{33}\right]$ \\
\hline $\mathrm{N}$ & $\mathrm{C}_{33} \mathrm{H}_{58}$ & 22R-trishomohopane $\left[\mathrm{C}_{33}\right]$ \\
\hline $\mathrm{O}$ & $\mathrm{C}_{34} \mathrm{H}_{60}$ & 22S-tetrakishomohopane $\left[\mathrm{C}_{34}\right]$ \\
\hline $\mathrm{P}$ & $\mathrm{C}_{34} \mathrm{H}_{60}$ & 22R-tetrakihomohopane $\left[\mathrm{C}_{34}\right]$ \\
\hline \multicolumn{3}{|r|}{ Steranes } \\
\hline 1 & $\mathrm{C}_{27} \mathrm{H}_{48}$ & $13 \beta, 17 \alpha, 20 \mathrm{~S}$-diacholestane $\left[\mathrm{C}_{27}\right]$ \\
\hline 2 & $\mathrm{C}_{27} \mathrm{H}_{48}$ & $13 \beta, 17 \alpha, 20 \mathrm{R}$-diacholestane $\left[\mathrm{C}_{27}\right]$ \\
\hline 3 & $\mathrm{C}_{27} \mathrm{H}_{48}$ & $13 \alpha, 17 \beta, 20$ S-diacholestane $\left[\mathrm{C}_{27}\right]$ \\
\hline $5 \mathrm{a}$ & $\mathrm{C}_{28} \mathrm{H}_{50}$ & $13 \beta, 17 \alpha, 20 \mathrm{~S}, 24-$ methyldiacholestane $\left[\mathrm{C}_{28}\right](\mathrm{I})$ \\
\hline $5 b$ & $\mathrm{C}_{28} \mathrm{H}_{50}$ & $13 \beta, 17 \alpha, 20 \mathrm{~S}, 24$-methyldiacholestane $\left[\mathrm{C}_{28}\right]$ (II) \\
\hline $7 \mathrm{a}$ & $\mathrm{C}_{28} \mathrm{H}_{50}$ & $13 \beta, 17 \alpha, 20 \mathrm{R}, 24-$ methyldiacholestane $\left[\mathrm{C}_{28}\right](\mathrm{I})$ \\
\hline $7 \mathrm{~b}$ & $\mathrm{C}_{28} \mathrm{H}_{50}$ & $13 \beta, 17 \alpha, 20 \mathrm{R}, 24$-methyldiacholestane $\left[\mathrm{C}_{28}\right]$ (II) \\
\hline 8 & $\mathrm{C}_{28} \mathrm{H}_{50}$ & $13 \beta, 17 \beta, 20 \mathrm{~S}, 24-$ methyldiacholestane $\left[\mathrm{C}_{28}\right]$ or $5 \alpha, 14 \alpha, 17 \alpha, 20 \mathrm{~S}$-cholestane [C27] \\
\hline 10 & $\mathrm{C}_{28} \mathrm{H}_{50}$ & $5 \alpha, 14 \alpha, 17 \alpha, 20 \mathrm{R}$-cholestane $\left[\mathrm{C}_{27}\right]$ or $13 \alpha, 17 \beta, 20 \mathrm{R}, 24$-methyldiacholestane [C28] \\
\hline 12 & $\mathrm{C}_{28} \mathrm{H}_{50}$ & $\begin{array}{l}5 \alpha, 14 \alpha, 17 \alpha, 20 \mathrm{~S}, 24-\text { methyldiacholestane }\left[\mathrm{C}_{28}\right]+5 \alpha, 14 \alpha, 17 \alpha, 20 \mathrm{~S}, 24 \text {-ethyldiacho- } \\
\text { lestane [C29] }\end{array}$ \\
\hline 13 & $\mathrm{C}_{28} \mathrm{H}_{50}$ & $5 \alpha, 14 \beta, 17 \beta, 20 \mathrm{R}, 24$-methyldiacholestane $\left[\mathrm{C}_{28}\right]$ \\
\hline 14 & $\mathrm{C}_{28} \mathrm{H}_{50}$ & $5 \alpha, 14 \alpha, 17 \alpha, 20 \mathrm{R}, 24$-methylcholestane $\left[\mathrm{C}_{28}\right]$ \\
\hline 15 & $\mathrm{C}_{29} \mathrm{H}_{52}$ & $5 \alpha, 14 \alpha, 17 \alpha, 20 \mathrm{~S}, 24$-ethylcholestane $\left[\mathrm{C}_{29}\right]$ \\
\hline 16 & $\mathrm{C}_{29} \mathrm{H}_{52}$ & $5 \alpha, 14 \beta, 17 \beta, 20 \mathrm{R}, 24$-ethylcholestane $\left[\mathrm{C}_{29}\right]$ \\
\hline 17 & $\mathrm{C}_{29} \mathrm{H}_{52}$ & $5 \alpha, 14 \beta, 17 \beta, 20 \mathrm{~S}, 24$-ethylcholestane $\left[\mathrm{C}_{29}\right]$ \\
\hline 18 & $\mathrm{C}_{29} \mathrm{H}_{52}$ & $5 \alpha, 14 \alpha, 17 \alpha, 20 \mathrm{R}, 24$-ethylcholestane $\left[\mathrm{C}_{29}\right]$ \\
\hline
\end{tabular}


The CAI isograds for the Middle Ordovician carbonates gradually increase eastward across the study area from 1.5 to 2.0 units (vitrinite reflectance equivalent $(\mathrm{VRE})=0.5$ to 1 percent) (Repetski and others, 2002; this volume, chap. F.1). These isograds indicate a "window" of oil and wet gas generation and preservation and thus also support the theory that oil was locally derived from the Utica Shale. Local oil derivation from the Utica is also suggested by the similarity between the carbon isotopic distributions of oil extracted from the Utica Shale in Coshocton County, Ohio (fig. 3) (depth is between 5,600 and 5,700 ft) and the distribution of oil of higher maturity from "Clinton" sandstone reservoirs (fig. 17). Moreover, the general eastward (basinward) increase in thermal maturity of the oils, based on (1) a comparison between $\mathrm{pr} / n-\mathrm{C}_{17}$ versus $\mathrm{pr} / n-\mathrm{C}_{18}$ (fig. 16) and (2) the carbon isotopic distributions (fig. 17), suggests that minimal lateral migration of oil had occurred before entrapment.

The oil sample from the No. 6 Weber well is anomalous because it is geochemically associated with oil of a lower thermal maturity (fig. 16) and geologically associated with the CAI 3 isograd (VRE $=2.25$ percent) (Repetski and others, 2002) that signifies the "window" of dry-gas generation and preservation. Either this oil was introduced from a source rock of lower thermal maturity, such as the overlying Devonian black shale, or the oil was locally preserved in a relatively high thermal regime that favored the generation and preservation of dry gas. In contrast, oil from the No. 3 Griffin well at a depth of about $3,900 \mathrm{ft}$ is geochemically associated with oil derived from rocks of higher thermal maturity oils whose depth of production is approximately $1,000 \mathrm{ft}$ greater. This oil may have migrated into the vicinity of the No. 3 Griffin well from deeper in the basin, or it may have resulted from a more mature secondary phase of generation that occurred beneath the well and was then trapped next to the oil derived from rocks of lower thermal maturity. Additional evidence for the mixing of several different oil types - either caused by a different source rock or thermal maturity regime - is suggested by the bimodal $n$-alkane distributions noted in several oil samples (see fig. 6B).

The following sequence of events represents one scenario for the origin of the oils: (1) oil was generated from the Utica Shale, (2) the oil migrated vertically into the overlying reservoir consisting of the "Clinton" sandstone and Medina Group sandstones, (3) the oil probably was trapped before significant lateral migration occurred, and (4) local mixing of oils from disparate thermal regimes occurred during late-stage basin uplift and erosion. This scenario suggests that the crude oils evolved later and were from a more local source than the natural gases described in the previous section.

\section{Acknowledgments}

Rick Liddle of Range Resources, Inc. (now Great Lakes Energy Partners) and Frank Carolas of Atlas Resources, Inc., enthusiastically gave permission and made arrangements for us to sample the wells. Assistance with field sampling was kindly and patiently provided by Earl (Pep) Horning, John Frederick, and Dave Smallwood, all of Range Resources, Inc. (now Great Lakes Energy Partners), and by Pete Burns of Atlas Resources, Inc.

\section{References Cited}

Barker, J.F., and Pollock, S.J., 1984, The geochemistry and origin of natural gases in southern Ontario: Bulletin of Canadian Petroleum Geology, v. 32, no. 3, p. 313-326.

Barton, G.L., Burruss, R.C., and Ryder, R.T., 1998, Water quality in the vicinity of Mosquito Creek Lake, Trumbull County, Ohio, in relation to the chemistry of locally occurring oil, natural gas, and brine: U.S. Geological Survey Water-Resources Investigations Report 98-4180, 46 p.

Brett, C.E., Tepper, D.H., Goodman, W.M., LoDuca, S.T., and Eckert, Bea-Yeh, 1995, Revised stratigraphy and correlations of the Niagaran provincial series (Medina, Clinton, and Lockport Groups) in the type area of western New York: U.S. Geological Survey Bulletin 2086, 66 p.

Chung, H.M., Gormly, J.R., and Squires, R.M., 1988, Origin of gaseous hydrocarbons in subsurface environments; theoretical considerations of carbon isotope distribution: Chemical Geology, v. 71, nos. 1-3, p. 97-103.

Cole, G.A., Drozd, R.J., Sedivy, R.A., and Halpern, H.I., 1987, Organic geochemistry and oil-source correlations, Paleozoic of Ohio: American Association of Petroleum Geologists Bulletin, v. 71, no. 7, p. 788-809.

Drozd, R.J., and Cole, G.A., 1994, Point Pleasant-Brassfield(!) petroleum system, Appalachian Basin, U.S.A., in Magoon, L.B., and Dow, W.G., eds., The petroleum system-From source to trap: American Association of Petroleum Geologists Memoir 60, p. 387-398.

Gautier, D.L., Dolton, G.L., Takahashi, K.I., and Varnes, K.L., eds., 1995, 1995 National assessment of United States oil and gas resources-Results, methodology, and supporting data: U.S. Geological Survey Digital Data Series DDS-30, 1 CD-ROM. (Data now available online at http://energy. usgs.gov/OilGas/AssessmentsData/NationalOilGasAssessment.aspx.)

Jenden, P.D., Drazan, D.J., and Kaplan, I.R., 1993, Mixing of thermogenic natural gases in northern Appalachian basin: American Association of Petroleum Geologists Bulletin, v. 77 , no. 6 , p. $980-998$.

Keighin, C.W., 1998, Depositional dip-oriented cross-section through the Lower Silurian "Clinton" sands and Medina Group in northeastern Ohio and western Pennsylvania: U.S. Geological Survey Open-File Report 98-500, 1 sheet. 
Laughrey, C.D., and Baldassare, F.J., 1998, Geochemistry and origin of some natural gases in the Plateau province, central Appalachian basin, Pennsylvania and Ohio: American Association of Petroleum Geologists Bulletin, v. 82, no. 2, p. 317-335.

Moore, B.J., 1982, Analysis of natural gases, 1917-1980: U.S Bureau of Mines Information Circular 8870, 1055 p.

Nöth, S., 1991, Die Conodontendiagenese als Inkohlungsparameter und ien Vergleich unterschiedlich sensitiver Diageneseindikatoren am Beispeil von Triassedimenten Nord- und Mitteldeutschlands: Bochumer Geologische und Geotechnische Arbeiten 37, 169 p.

Obermajer, M., Fowler, M.G., and Snowdon, L.R., 1998, A geochemical characterization and a biomarker re-appraisal of the oil families from southwestern Ontario, Canada: Bulletin of Canadian Petroleum Geology, v. 46, no. 3, p. 350-378.

Palmer, A.R., compiler, 1983, The Decade of North American Geology 1983 time scale: Geology, v. 11, no. 9, p. 503-504.

Powell, T.G., Macqueen, R.W., Barker, J.F., and Bree, D.G., 1984, Geochemical character and origin of Ontario oils: Bulletin of Canadian Petroleum Geology, v. 32, no. 3, p. 299-312.

Repetski, J.E., Ryder, R.T., Harper, J.A., and Trippi, M.H., 2002, Thermal maturity patterns (CAI and $\% \mathrm{R}_{\mathrm{o}}$ ) in the Ordovician and Devonian rocks of the Appalachian basin in Pennsylvania: U.S. Geological Survey OpenFile Report 02-302, 57 p., accessed June 23, 2006 at http://pubs.usgs.gov/of/2002/of02-302/.
Ryder, R.T., 1998, Characteristics of discrete and basincentered parts of the Lower Silurian regional oil and gas accumulation, Appalachian basin; preliminary results from a data set of 25 oil and gas fields: U.S. Geological Survey Open-File Report 98-0216, 71 p., accessed June 23, 2006 at http://pubs.usgs.gov/of/1998/of98-216/.

Ryder, R.T., 2000, Stratigraphic framework and depositional sequences in the Lower Silurian regional oil and gas accumulation, Appalachian basin; from Jackson County, Ohio, through northwestern Pennsylvania, to Orleans County, New York: U.S. Geological Survey Geologic Investigations Series Map I-2726, 2 sheets, pamphlet, 8 p. (Also available online at http://pubs.usgs.gov/imap/i-2726.)

Ryder, R.T., Burruss, R.C., and Hatch, J.R., 1998, Black shale source rocks and oil generation in the Cambrian and Ordovician of the central Appalachian basin, USA: American Association of Petroleum Geologists Bulletin, v. 82, no. 3, p. 412-441.

Ryder, R.T. and Zagorski, W.A., 2003, Nature, origin, and production characteristics of the Lower Silurian regional oil and gas accumulation, central Appalachian basin, United States: American Association of Petroleum Geologists Bulletin, v. 87, no. 5, p. 847-872.

Schoell, Martin, 1983, Genetic characteristics of natural gases: American Association of Petroleum Geologists Bulletin, v. 67 , no. 12 , p. $2225-2238$. 